JANUSZ ŻARNOWSKI

Warszawa

\title{
INTELIGENCJA POLSKA, JEJ EWOLUCJA HISTORYCZNA PRZED WOJNĄ I W DOBIE POWOJENNEJ
}

Zarys treści: Autor, który przez wiele dziesięcioleci zajmował się historią inteligencji polskiej w latach międzywojennych, rozszerza swe zainteresowania na cały okres XX i początki XXI w. Dochodzi do wniosku, że inteligencja jako warstwa społeczna zaczyna być mniej ważna od inteligencji w rozumieniu elity kulturowej i intelektualnej. Szkic rysuje w skrócie jej dzieje.

The content outline: The author who, for many decades, worked on the history of Polish intelligentsia in the interwar period, extends his scholarly interest to the whole twentieth and the early twenty-first century. He concludes that the intelligentsia as a social strata begin to be less important than the intelligentsia as a cultural and intellectual elite. The present study sketches a summary of the intelligentsia's history.

Słowa kluczowe: kultura narodowa, inteligencja, intelektualiści, liberalizm społeczny, awans społeczny, komunizm, globalizacja społeczna i kulturowa

Keywords: national culture, intelligentsia, intellectuals, social liberalism, social advancement, communism, social and cultural globalisation

\section{Uwagi wstępne}

W badaniu struktur społecznych (a także wszelkich innych obiektów poznania naukowego) możliwe są różne znaczenia i odmienne definicje tego samego przedmiotu. Inteligencja (w znaczeniu społecznym) to pojęcie o szerokim zasięgu i niejednoznaczne. Witold Kula w recenzji mojej pracy habilitacyjnej, która była książka o inteligencji wydana w 1964 r., życzył mi drugiego tomu - rozumiem, że odnoszącego się do 
dziejów intelektualnych i kultury ${ }^{1}$. Mamy więc tu już dwie koncepcje tego samego pojęcia - inteligencja jako warstwa społeczno-zawodowa, ale też jako elita intelektualna narodu, nosiciel i krzewiciel kultury narodowej. Możliwe były wówczas (i są nadal) także inne koncepcje, jak - tytułem przykładu - kontynuacja warstwy szlacheckiej jako tradycyjnej elity polskiej w warunkach pouwłaszczeniowych i w późniejszych epokach (tu kłania się pół żartem, pół serio wymieniana matura jako odpowiednik klejnotu szlacheckiego), a także inteligencja jako kategoria skupiona na zadaniach narodowych (to zwłaszcza przed odzyskaniem niepodległości) czy społecznych (to szczególnie w niepodległym państwie, ale pamiętajmy też dla czasów wcześniejszych o symbolach takich jak Judym i Siłaczka) i wiele jeszcze innych.

Przedstawię tu rozważania na temat dziejów inteligencji od $1918 \mathrm{r}$. do naszych czasów w wersji odnoszącej się do inteligencji jako środowiska tworzącego, przechowującego i rozpowszechniającego kulturę narodowa. Wersja ta eksponuje czynnik intelektualno-kulturowy.

Moja ksiażka z 1964 r. omawiała aspekt strukturalny, któremu poświęciłem wiele lat pracy i refleksji, obraz inteligencji wynikający z tej drugiej definicji mogę jedynie zarysować. W zakończeniu tego tekstu zestawię je ze sobą i spróbuję sformułować nasuwające się wnioski.

Tekst poświęcony inteligencji jako elicie kulturalnej i intelektualnej szkicuje nowe horyzonty w porównaniu do tekstów odnoszących się do inteligencji jako warstwy społecznej, ale też inaczej zakreśla zasięg tej elity. W zamierzeniu autora mógłby stanowić podstawę do dyskusji na temat użyteczności nowej wersji pojęcia inteligencji dla posunięcia naprzód prac badawczych nad społeczeństwem polskim w XX i XXI w. Trzeba by zweryfikować zasięg i granice inteligencji w nowym, skorygowanym rozumieniu, zastanowić się nad pozytywnymi cechami tego nowego oglądu i nad tym, w jakim zakresie odbija on rzeczywiście istniejące i funkcjonujace środowiska i grupy społeczne. Wreszcie przedmiotem dyskusji mogłyby stać się szkicowo i w skrócie przedstawione kierunki przemian i ewolucji omawianej tu formacji. Gdyby oceny były pozytywne, nie wątpię, że w przyszłości badacze dziejów społeczeństwa polskiego potrafiliby przedstawić wersję pełniejszą i bardziej rozbudowana.

1 J. Żarnowski, Struktura społeczna inteligencji $w$ Polsce $w$ latach 1918-1939, Warszawa 1964, zob. rec. W. Kuli: Zagadka inteligencji polskiej, „Kwartalnik Historyczny" 72,1965 , s. 100-101. 


\section{Inteligencja jako elita kulturowa i intelektualna}

W ogłoszonych już tekstach zrekapitulowałem moje ponad półwiekowe prace i refleksje nad warstwą inteligencji, która być może jest już dziś raczej obiektem historycznym niż realnym tworem społecznym $^{2}$. Wspomniano już o teoretycznie nieograniczonych możliwościach badania tego samego zjawiska na podstawie różnych definicji. Wcześniej już nadmieniłem, że wyboru podstawowego oglądu naszej warstwy społecznej dokonałem przed laty w przekonaniu, że struktura społeczna to podstawowa, najważniejsza i najbardziej w ówczesnych warunkach przydatna rama rozważań nad inteligencją. Skoro wydaje się, że żywot inteligencji rozumianej w ten sposób dobiega końca, to czy nie będzie słuszne zbadać, jak sprawa się przedstawia, jeśli zastanowimy się nad losami tej kategorii rozumianej nieco inaczej. Nawiązuję tu do uwagi Witolda Kuli do mojej pracy o inteligencji z 1964 r., sformułowanej w przywołanej na początku tego tekstu recenzji. Rozumie się, że w niniejszym tekście chodzi o rys syntetyczny inteligencji jako ośrodka tworzenia, rozwijania i rozpowszechniania kultury narodowej, przedstawiony na podstawie dotychczasowych badań i ogólnej znajomości przedmiotu. Do pełnego wykonania zalecenia Witolda Kuli trzeba by lat pracy, tu idzie o przegląd stanowiący raczej próbę rekonesansu niż systematycznego wykładu.

Kolejną więc definicją byłaby tu inteligencja jako elita intelektualna spoleczeństwa i narodu, twórca i krzewiciel kultury narodowej. To jest chyba najważniejsza rola inteligencji, której nie oddaje definicja warstwy społecznej. Inne zaś definicje czy związane z nimi kierunki badań, których przykłady podałem na początku niniejszego opracowania, maja już albo mniejsze, albo po prostu czysto historyczne znaczenie.

Zacznę od cytatu z trzeciego tomu trylogii - historii inteligencji polskiej doby rozbiorowej pod redakcja Jerzego Jedlickiego. „Kultura polska $\mathrm{w}$ zetknięciu z trzema dominującymi, nierzadko pod względem cywilizacyjnym wyżej od niej stojacymi kulturami potęg zaborczych, zachowała tyle wewnętrznej spójności, że w 1918 roku można było -

2 J. Żarnowski, Nowe spojrzenie na społeczeństwo Polski międzywojennej, w: Spoteczeństwo międzywojenne. Nowe spojrzenie, red. W. Mędrzecki, J. Żarnowski, Warszawa 2015 (Metamorfozy Społeczne, 10), s. 13-46; tenże, Inteligencja jako warstwa społeczna w Polsce (od 1918 do wspótczesności), w druku przez IPN Oddział w Lublinie, w tomie zawierającym materiały konferencji naukowej „Inteligencja w Polsce w latach 1914-1989. Ewolucja struktury, roli i postaw" - Lublin, 26-28 IX 2017 r.; zob. też inne moje dawniejsze prace: Struktura społeczna inteligencji $w$ Polsce...; Społeczeństwo Drugiej Rzeczypospolitej: 1918-1939, Warszawa 1973. 
pomimo widocznych różnic międzyzaborowych - mówić o jej jedności ponad wszystkimi podziałami. Umocnienie i obrona tej jedności na przestrzeni przeszło stulecia były z pewnością największą zasługa inteligencji polskiej doby rozbiorów. W 1918 roku również idea irredenty i budowy zrębów własnej państwowości okazała się osia, wokół której można było zjednoczyć istotną część społeczeństwa polskiego, a przecież przez znaczący okres epoki rozbiorowej to właśnie inteligencja była ważna, a przez wiele dziesięcioleci najważniejsza propagatorka tej idei" ${ }^{3}$. Cytat ten wprowadza nas in medias res problematyki zwiazanej z inteligencja jako ośrodkiem i depozytariuszem kultury narodowej, w momencie, od którego zaczęła się praktycznie historia Polski i jej społeczeństwa w XX w.

Ale kto był bohaterem tych zmagań, kim była inteligencja, która obroniła spójność kultury narodowej, a teraz zabrała się do „budowy zrębów własnej państwowości", która pisała wszystkie ustawy, podręczniki szkolne i książeczki dla dzieci, układała regulaminy wojskowe i więzienne, ale też nowe powieści i sztuki teatralne, poezję Skamandrytów i Przedwiośnie, Wiatr od morza, Noce i dnie, 2 Koncert skrzypcowy i Harnasie Karola Szymanowskiego, szkicowała projekty nowych budynków rządowych w Warszawie i projektowała pawilony na wystawach paryskich w 1925 i 1937 r.? To środowisko bez porównania węższe niż warstwa będąca przedmiotem mojej pracy z $1964 \mathrm{r}$. Ale jednak szersze niż sami tylko pisarze i malarze czy wybitni uczeni, np. profesorowie nowych uniwersytetów polskich, niż „intelektualiści” - termin wchodzący wówczas dopiero w użycie.

Poprzednia epoka pozostawiła ludzi o wysokim autorytecie i wysokim poziomie intelektualnym, którzy nieraz sprawowali całkiem skromne funkcje zawodowe. Tu przychodzi mi na myśl Stanisław Stempowski. Ale nie to było najdonioślejsze. Spośród ludzi wykształconych jeszcze przed wojna światowa, ale $\mathrm{z}$ dodatkiem młodego pokolenia wychowanego już na polskich uczelniach lub $\mathrm{w}$ polskich ośrodkach artystycznych, wytworzyła się kategoria świadomych i aktywnych odbiorców wartości kultury społecznej, intelektualnej i artystycznej. Środowisko to było naturalnie przedłużeniem podobnego środowiska przedwojennego, ale zmiany, które nastapiły w latach 1914-1920, całkowicie zmieniły jego obraz. Charakteryzowało się na ogół aktywnością społeczna na różnych szczeblach, nie wyłączając państwowego i politycznego. Częścia tego środowiska byli twórcy dzieł literackich, artystycznych

${ }^{3}$ M. Micińska, Inteligencja na rozdrożach 1864-1918, Warszawa 2008 (Dzieje inteligencji polskiej do roku 1918, 3), s. 190-191. 
i naukowych. Bez szerszego środowiska kompetentnych i wysoce zainteresowanych odbiorców kultury twórcy w większości wypadków nie mogliby funkcjonować. Tworzyli swe dzieła najczęściej z myślą o ich opinii. Oczywiście i wewnątrz tej kategorii odbiorców kultury kompetencje były zróżnicowane, a różnice nie zawsze uchwytne. Omawiane środowisko było bez wątpienia znacznie szersze od samych tylko ośrodków twórczych.

Ale nie wszyscy przedstawiciele warstwy oświeconej tworzących kategorię, która pragniemy tu bliżej określić, należeli do grona znawców konkretnego kierunku twórczości. Do tej grupy należeli także często ludzie wykształceni, związani z zawodami praktycznymi. Było tam wielu świadomych uczestników życia kulturalnego kraju, których punkt ciężkości zainteresowań wychodził poza określona gałąz sztuki czy nauki. Te różne kategorie i środowiska tworzyły wielki krąg uczestników wyższej kultury w Polsce, przede wszystkim uczestników kultury narodowej, który stanowić może przedmiot nowego opracowania.

Wszystkie te środowiska mieściły się przeważnie wewnątrz inteligencji zawodowej, której kategorie wymieniałem jako elementy warstwy społecznej, i były zarazem częścią inteligencji w obecnie omawianym znaczeniu. Niekiedy mamy do czynienia z wyodrębnionymi środowiskami artystycznymi czy naukowymi, o charakterze autonomicznym, ale też zintegrowanymi z warstwą inteligencji ${ }^{4}$. Ale wchodzą tu $\mathrm{w}$ grę również zainteresowane problemami społecznymi i kultura środowiska inteligencko-mieszczańskie, ziemiańskie, a nawet mniejszościowe, pozostające na tym samym poziomie kulturalnym. W sumie to dziesiątki, może setki tysięcy, ale na pewno nie miliony ${ }^{5}$. W tych środowiskach szukać należy inteligencji w obecnie omawianym znaczeniu kulturalnej elity społeczeństwa narodowego ${ }^{6}$. Lecz na tych niezbyt licznych grupach i ośrodkach wzorowały się pod wieloma względami setki tysięcy, a w porywach może nawet miliony pracowników umysłowych,

4 Tu jako przykład przychodzi mi do głowy środowisko wydawców, autorów i redaktorów „Wiadomości Literackich”, stanowiące przez lata trwałą instytucję w życiu kulturalnym, albo poszczególne środowiska naukowe związane z uniwersytetami - nie trudno zgadnąć, że mam na myśli m.in. historyków.

${ }^{5}$ S. Żółkiewski obliczał publiczność czytajacca (niekoniecznie co dzień) gazety na ok. 3 mln, czytelników książek w połowie dwudziestolecia na 700-750 tys. (z pominięciem czytelników przymuszonych, a więc uczniów szkół i nawet studentów), a publiczność literacka czytająca dzieła artystyczne stanowiła tylko czastkę tej liczby. Około dwóch trzecich stałych czytelników książek stanowiła tradycyjna publiczność inteligencka; zob. tenże, Kultura literacka 1918-1932, Warszawa 1973, s. 282, passim.

${ }_{6}^{6}$ Mowa o społeczeństwie narodowym, elita taka nie istnieje bowiem poza jego ramami. 
drobnomieszczaństwa, lepiej wykształconych i sytuowanych robotników oraz ludzi z innych środowisk.

Tego rodzaju elita istnieje $\mathrm{w}$ każdym nowoczesnym społeczeństwie kultury europejskiej i, zapewne, poza Europa. W naszym wypadku ważny jest stosunek tej elity do pojęcia inteligencji funkcjonującego w Polsce od XIX w. Inteligencja tworzyła w niepodległej Polsce i później rodzaj warstwy społecznej, która wykraczała daleko poza pojęcie elity intelektualnej. Istniała świadomość rozbieżności tych znaczeń, a w wielu dyskusjach światopoglądowych, politycznych i kulturalnych używano pojęcia inteligencji we wspomnianym znaczeniu elity, nie troszcząc się nadmiernie o jego wieloznaczność. Znaczna część ówczesnej warstwy zwanej tradycyjnie inteligencja, obejmująca m.in. środowiska urzędnicze, administracyjne albo zatrudnionych w branżach gospodarczych, w ogóle nie rozumiałaby zapewne toczonych w łonie elity rozważań o problematyce kulturowej czy socjologicznej, odnoszacych się do roli inteligencji w Polsce i do problemów, jakie stały w tym czasie przed polskim społeczeństwem - gospodarzem nowo powstałego państwa.

Elita, o której mowa, posiadała odpowiednie organizacje i stowarzyszenia (np. stowarzyszenia naukowe, profesjonalne, organizacje artystów, nawet związek kobiet $\mathrm{z}$ wyższym wykształceniem ${ }^{7}$ ), swoje czasopisma, a zatem spełniała niektóre cechy charakterystyczne dla odrębnej kategorii społecznej.

Przy takim ujęciu inteligencja w tym „nowym” znaczeniu miałaby charakter głównie humanistyczno-literacki i prawniczy, a przecież odczuwamy przynależność do niej środowisk wysoko wykształconych i twórczych z zakresu, dajmy na to, techniki czy umiejętności praktycznych, spośród których na czoło wysuwają się np. lekarze i inne zawody medyczne. Najważniejszym kryterium był poziom kulturalny, umożliwiający udział w życiu kulturalnym kraju, w tym udział twórczy w pełnym tego słowa znaczeniu. Jeśli elementem decydujacym miała być twórczość, to punktem stycznym były szkoły akademickie czy w ogóle szkoły wyższe, związane organicznie z twórczością i kulturą narodowa. Pojęcie twórczości w odniesieniu do tego środowiska należałoby rozszerzyć, zdecydowanie wykraczając poza profesjonalna twórczość artystyczna, naukową i ideowa, i szukając momentu twórczego wzbogacajacego poziom kultury szerszych środowisk społecznych, także w zajęciach innych niż czysto artystyczne czy naukowe.

7 Jest nawet praca Marii Wierzbickiej na ten temat, zamieszczona w zbiorze Dziataczki spoteczne, feministki, obywatelki... Samoorganizowanie sie kobiet na ziemiach polskich po 1918 roku (na tle porównawczym), t. 2, red. A. Janiak-Jasińska, K. Sierakowska, A. Szwarc, Warszawa 2009. 
Jakkolwiek by to uczynić, jasna jest rzecza, że tak rozumiana inteligencja nie była (i nie jest) policzalna i nie nadaje się do operacji statystycznych, jakie stosowałem w stosunku do inteligencji jako warstwy społeczno-zawodowej. Wielu uczestników tej grupy pełniło podwójna rolę jako „zawodowi inteligenci”, zatrudnieni w jednym z inteligenckich zawodów, niekiedy w prostej pracy urzędniczej, a równolegle byli twórcami czy częściej jeszcze odbiorcami twórczości artystycznej czy naukowej, a zwłaszcza świadomymi uczestnikami życia kulturalnego. Z drugiej strony daleko nie wszyscy „zawodowi inteligenci”, nawet z formalnie odpowiednim wykształceniem, reprezentowali odpowiedni poziom i możliwości intelektualne, jak również odpowiednie zainteresowania, by traktować ich jako część elity intelektualnej. Nie można byłoby nawet wówczas, nie mówiąc już o naszym oddaleniu czasowym od tych czasów, ustanowić jakichś zbiorowych wyznaczników przynależności, gdyż miały one czysto indywidualny charakter.

Zdaję sobie sprawę, że z punktu widzenia ścisłej klasyfikacji moje rozważania $\mathrm{w}$ tym punkcie można by podważyć. Najpierw należałoby dowieść istnienia i odrębności opisywanych tu kategorii, a potem dopiero omawiać ich rolę. Z drugiej strony jednak trudno nie zauważyć w ówczesnych dyskusjach wieloznaczności pojęcia inteligencji, którego jedna z wersji zdawała się odpowiadać naszej propozycji.

Kilka zdań należy poświęcić charakterystyce ówczesnej inteligencji jako spadkobiercy ery zaborowej. W analizowanym momencie różnice międzydzielnicowe były szczególnie ważne i widoczne. Omawiana przez nas warstwa przeszła przez wstrzasy wojenne lat 1914-1920 i wielka jej część utraciła swe dawne siedziby. Odnosiło się to zwłaszcza, choć nie tylko, do przedwojennych inteligentów czy środowisk twórczych z tzw. Ziem Zabranych, z Petersburga czy z głębi Rosji. A ta kategoria środowisk związanych z kultura narodowa i inteligencja polska odgrywała przed 1914 r. znaczną rolę. Wychodźcy ci, których wielu wróciło do kraju, pozostali po wojnie częścią środowiska kulturotwórczego.

Z natury rzeczy mieszkańcy centralnej Polski, dawnego Królestwa Polskiego, którzy nie zostali zmobilizowani czy ewakuowani przez władze carskie, mieli łatwiejszy dostęp do odbudowującej się kultury i instytucji polskich, a to $\mathrm{w}$ zwiazku $\mathrm{z}$ planami państwowymi wobec Polski omawianymi między mocarstwami centralnymi i podejmowanymi przez Niemcy przygotowaniami do utworzenia polskiego Nebenlandu. Polska inteligencja była w przeszłości okaleczona przez reżim carski, nie tylko na Ziemiach Zabranych, ale i w Królestwie, i jej jedyną nadzieją było wyzwolenie kraju spod obcej władzy. Była też najbardziej aktywna we wszystkich działaniach w tym kierunku, ale jej przygotowanie, przede 
wszystkim z winy caratu, pozostawiało wiele do życzenia. Już wówczas tworzac np. instytucje naukowe, Warszawa musiała odwoływać się do pomocy inteligencji galicyjskiej, której historia dała możliwość studiów i działania o 50 lat wcześniej niż inteligentom z Warszawy.

Toteż Galicja, choć nie tylko ona, bo Królestwo także, stała się rezerwuarem kadr, które, wraz z polską administracją i szkolnictwem, „najechały" na zabór pruski i ziemie wschodnie. Mimo to Galicja pozostała nadal terenem bodaj największego zagęszczenia warstwy wykształconej polskiej i żydowskiej, co w żadnym razie nie skłaniało obu stron do życia w idealnej zgodzie. W Polsce centralnej trwał proces wyrównywania luk w wykształceniu wielu ludzi, nie tylko wykonujacych zawody inteligenckie, ale należących do elity inteligenckiej, albo do niej aspirujących, którym nie udało się z różnych względów ukończyć studiów wyższych. Niekiedy odbywało się to w drodze różnych zabiegów zastępczych i głównie dokonywało się w latach 20. Młode pokolenie z tego obszaru nie miało już takich problemów i mogło zdobyć odpowiednie wykształcenie.

Ziemie wschodnie stanowiły pewien wentyl bezpieczeństwa, przynajmniej dla polskiej inteligencji, która potrzebowała etatów w służbie państwowej i samorządowej, choć ze względu na swe zacofanie i ogólna biedę ludności były zarazem traktowane jako teren zesłania urzędników i nauczycieli, niechętnie widzianych w reprezentacyjnych centrach kraju. Nieliczne inteligenckie elity polskie z Poznańskiego miały wiele do załatwienia jako autonomiczny zarządca swej dzielnicy w czasach Ministerstwa byłej Dzielnicy Pruskiej (do 1922 r.), później ich część stała się integralną częścią elit ogólnopolskich.

Okres międzywojenny stał się apogeum tej roli inteligencji polskiej, którą obecnie omawiamy. Nigdy dotąd ani nigdy później takiej roli nie spełniała. Natychmiast po odbudowie państwa właściwie tylko polska inteligencja mogła uczestniczyć w ustaleniu nowych norm funkcjonowania systemu politycznego i prawnego, krzewienia i upowszechnienia kultury. W pewnym sensie to inteligencja pisała konstytucje, ustawy i rozporządzenia, programy i podręczniki szkolne, regulaminy wojskowe i ordynacje skarbowe. Wprawdzie w mikroskopijnej skali już za czasów Rady Stanu i Rady Regencyjnej inteligencja, głównie warszawska, przygotowywała pewne obszary nowej Polski, od stosunków zagranicznych i spraw wojskowych po opiekę społeczną i szkolnictwo, ale ciążyła nad nią nie tylko przemoc niemiecka, lecz i Rada Regencyjna, złożona z księcia, obszarnika i arcybiskupa. Zaczęła się epoka, którą Maria Dąbrowska opisuje w swym dzienniku, „gdy służba w powstającej biurokracji rządowej wydawała się - i poniekąd była - wymarzoną od pokoleń 
służbą wyśnionemu Państwu”. Nie mogło to nie przynieść, wkrótce albo nieco później, wielu rozczarowań. Wkrótce bowiem „Państwo” przestało być nadrzędnym bóstwem i nabrało kolorów partyjnych. Nie można było służyć mu inaczej niż za pośrednictwem różnych partii i obozów politycznych. Okazało się to już w czasie wyborów parlamentarnych $1922 \mathrm{r}$.

Inteligencja także podlegała tym procesom i skupiała się głównie w dwóch orientacjach: lewicowo-legionowo-liberalnej i nacjonalistyczno-prawicowej. Zamach majowy dał przewagę pierwszemu z tych obozów, który utracił charakter lewicowy i nabrał cech autorytarnych, podobnie zreszta jak i obóz przeciwny, a wszystko to zgodnie z duchem epoki, w której narodził się totalitaryzm. Jednak poważny autorytet zachowała nadal inteligencja liberalna, częściowo lewicowa, która w kręgach intelektualnie twórczych miała znacząca przewagę aż po koniec epoki międzywojennej. Sytuacja ta sięgała do czasów przedwojennych, gdy powstawał obóz „niepodległościowy”, związany z Piłsudskim, PPS i różnymi środowiskami lewicowo-liberalnymi, które w całej Europie na przełomie wieków przeważały w ówczesnym młodym pokoleniu warstwy wykształconej. Po wojnie tym wszystkim grupom i środowiskom patronował w Polsce obóz legionowy i oczywiście było im później bliżej do sanacji niż do endecji. Stąd zaskakujące nieraz posunięcia i projekty władz w dziedzinie szkolnictwa czy polityki społecznej albo kulturalnej, pochodzace z repertuaru kultury świeckiej o zabarwieniu liberalno-demokratycznym, nawet już w czasie, gdy sanacja zdążała w kierunku autorytaryzmu, a na horyzoncie były wyraźne objawy totalizmu. Fakt, że alternatywą był obóz endecko-oenerowski w oczywisty sposób spajał te środowiska inteligenckie z obozem, który one same nazwałyby raczej legionowym niż sanacyjnym. W każdym razie mimo wszelkich frustracji inteligencja jako całość, a w każdym razie znakomita jej większość, nie odczuwała takiej obcości wobec władzy jak to było później w PRL. Oczywiście prawicowo nastawione grupy inteligencji ostro tę władzę krytykowały, ale to z zupełnie innych pozycji. Była to bądź co bądź władza powstała w ramach samego społeczeństwa polskiego.

Z ostrożności wypowiem myśl oczywistą dla historyka, choć w bieżących dyskusjach często pomijaną: „liberalna inteligencja” w roku np. 1900, 1926 czy 1939 znaczy coś innego niż ten sam termin w czasach współczesnych. Podobnie wszelkie inne pojęcia polityczne, światopoglądowe czy odnoszące się do filozofii społecznej. Ówczesne terminy polityczne nie są dzisiejszymi określeniami i ich mylenie ze sobą może

${ }^{8}$ M. Dąrowska, Dzienniki 1914-1965 w 13 tomach, t. 1: 1914-1925, Warszawa 2009, s. 147 n. 
wprowadzić w błąd. To nie znaczy jednak, że nie ma nic wspólnego między np. liberalizmem (termin bardzo wieloznaczny) sprzed 150 czy 100 lat a obecnymi kierunkami politycznymi przyznającymi się do tej nazwy, to samo dotyczy, powiedzmy, nacjonalizmu, tyle że do niego prawie nikt się wprost nie przyznaje. Może warto będzie przytoczyć takie pojęcia jak „wiek liberalizmu”, czyli wiek XIX, przeciwstawiony stuleciu XX jako wiekowi nacjonalizmu, totalitaryzmu, początków globalizmu itd. Chodzi mi o to, że ten sam prąd intelektualny w odmiennym otoczeniu i w innej epoce odgrywać może całkiem inną rolę niż podobnie zwany prąd w dawniejszej epoce. Kto wie, czy przedstawicielom ówczesnego liberalizmu przyszłyby do głowy pewne pomysły na organizację życia społecznego dziś przedstawiane jako sztandarowy dorobek tegoż kierunku.

Te dwie orientacje nie wyczerpuja całego spectrum politycznego, ale inne istniejące, takie jak konserwatywna czy ludowcowa albo wyraźnie lewicowa w odmianie socjalistycznej czy nawet komunistycznej, były mniej typowe dla inteligencji polskiej i spychane przez wydarzenia $\mathrm{w}$ kierunku jednego lub drugiego $\mathrm{z}$ dwóch wymienionych najważniejszych obozów.

Nie odważyłbym się jednak orzekać o ogólnym obliczu światopoglądowym czy politycznym inteligencji w krótkim stosunkowo okresie międzywojennym. Z moich rozważań o przetrwałej z poprzedniej epoki dominacji idei liberalnych wśród warstwy twórczej nie wynika jasny obraz podziałów światopoglądowych w łonie inteligencji jako całości $\mathrm{w}$ epoce międzywojennej. Tradycyjne związki rodzinne i towarzyskie, jak również powiązania z Kościołem tej licznej części inteligencji, która pochodziła ze środowisk postszlacheckich, a także tej znacznie mniej licznej, pochodzącej z drobnomieszczaństwa czy ze środowiska chłopskiego, skłaniają do ostrożności w tej kwestii.

Trudno jednak nie wspomnieć o objawach frustracji w łonie liberalnej inteligencji, zaostrzonych zwłaszcza w okresie po śmierci marszałka Piłsudskiego i zwrocie w obozie rządzącym. Dobrze obrazują te frustracje wspomniane już Dzienniki Marii Dąbrowskiej. Jednak jakieś związi tej inteligencji z rządzącym obozem, któremu zresztą wiele brakowało do spójności, pozostały nadal czynne. W końcu nie brakło związów z przeszłości, a także towarzyskich kontaktów aktualnych, o czym także pisze Dąbrowska, a również i inni wybitni pisarze tego okresu we wspomnieniach.

Trzeba też z drugiej strony wspomnieć o tym, co dziś bywa na ogół przemilczane: wśród inteligencji wywodzącej się z lewicy, lecz także z kół liberalnych, występowały mniej lub bardziej salonowe sympatie komunistyczne. Mowa tu nie tyle o komunistach partyjnych, ich losy, 
częstokroć tragiczne, były częściowo okryte tajemnicą i początkowo szerzej nieznane. Mam raczej na myśli sympatie dla ideowej działalności konspiracyjnej, pozostałe sprzed 1914 r., prowadzące np. do składania ofiar na Czerwoną Pomoc. Najwięcej takich sympatii było wśród młodszej części inteligencji pochodzenia żydowskiego, najczęściej polskojęzycznej i mniej lub bardziej asymilującej się do kultury polskiej. Inna rzecz, że z tego środowiska pochodziło też najwięcej partyjnych komunistów-inteligentów. Zanim świadomość zbrodni stalinizmu została przyjęta i uwiarygodniona jako prawda, a nie „propaganda burżuazyjna”, upłynęło sporo czasu i nadeszła wojna. Zjawisko to wykraczało poza Polskę i uwidoczniło się znacznie szerzej w zachodniej Europie. Sądzę, że echa tej sytuacji odzywały się $\mathrm{w}$ tych kołach inteligencji także po II wojnie światowej, gdy na porządku dziennym stanęła sprawa udziału w „budownictwie socjalistycznym".

Dodać tu należy jeszcze jedną okoliczność, która miała duże znaczenie dla inteligencji - elity intelektualnej, a odnosząca się właśnie do omawianego środowiska. To asymilacja licznej grupy z pogranicza polsko-żydowskiego do polskiej inteligencji. Sporo twórców kultury, i to wysokiego kalibru, pochodziło z tego pogranicza, przy czym zakres asymilacji wzrósł $\mathrm{w}$ okresie międzywojennym mimo rosnącego antysemityzmu i konfliktów, szczególnie żywych w młodym pokoleniu. Przede wszystkim jednak pogranicze polsko-żydowskie zasiliło warstwę odbiorców kultury polskiej. Odrębną sprawą były związki tych grup ze społeczeństwem żydowskim, które mogły być różnej mocy, od silnych do słabych, co oczywiście podlegało ewolucji ${ }^{9}$. Ale tych skomplikowanych spraw nie możemy tu omawiać szczegółowo, bo wykraczają poza nasz temat i kompetencje, natomiast trzeba o nich wspomnieć szczególnie w kontekście wojny, migracji, ale zwłaszcza funkcjonowania inteligencji w Polsce po II wojnie światowej.

Osiagnięcia państwa polskiego w okresie międzywojennym były niemałe i zdecydowały, że po II wojnie światowej nikt bezpośrednio nie kwestionował już jego istnienia jako pełnoprawnego i samodzielnego tworu, jak to było przed 1914 r. i jeszcze w czasie okupacji niemiecko-austriackiej $^{10}$. W gruncie rzeczy wszystkie one stanowiły owoc działalności

9 Wypada tu zacytować książkę Anny Landau-Czajki, poświęconą asymilacji ludności żydowskiej w Polsce w latach 1918-1939: Syn będzie Lech... Asymilacja Żydów $w$ Polsce międzywojennej, Warszawa 2006, zob. zwłaszcza Zakończenie, s. 433 n.

${ }^{10}$ Oczywiście rzeczywistość po 1945 r. była zupełnie inna, zwracam tu tylko uwagę na fakt, że państwa centralne aż do ostatecznej klęski miały zamiar powołać państwo polskie zależne nawet formalnie od Rzeszy (albo od Austrii), i znajdowały rozmówców po stronie polskiej nawet jeszcze w $1918 \mathrm{r}$. 
inteligencji, jeśli nie w całości, to w każdym razie w zakresie inicjatywy, planowania i dążenia do podniesienia standardów polskiego życia społecznego i państwowego do poziomu krajów uznawanych ówcześnie za przodujące cywilizacyjnie ${ }^{11}$. Trudno byłoby wymienić dziedzinę życia państwowego, w której inteligencja nie miałaby zasadniczego udziału. Dotyczy to armii, administracji, szkolnictwa, polityki społecznej i ochrony zdrowia, a w znacznym stopniu także finansów i bankowości. W mniejszej mierze inteligencja - w rozumieniu obecnie rozważanym - miała wpływ na całokształt życia gospodarczego i realne zarządzanie gospodarka, a także na decyzje strategiczne w dziedzinie polityki ogólnej, społecznej i gospodarki. Natomiast całokształt osiagnięć polskiej kultury umysłowej i artystycznej tego okresu to dzieło inteligencji. Trudno nie rozpatrywać tej karty dziejów inteligencji także na płaszczyźnie narodowo-państwowej, gdyż bez tego składnika funkcjonowanie państwa narodowego nie byłoby możliwe.

Gdy rozważamy te problemy, nie możemy pominać różnic między inteligencją jako grupą społeczną zwiazaną przede wszystkim z kultura narodowa a inteligencja jako warstwa w znacznej mierze urzędniczo-administracyjna, gdy chodzi o ocenę jej wpływu na procesy społeczne czy wydarzenia kulturalne. Jeśli chodzi o politykę gospodarczą państwa, przedmiot tak żywotny w okresie przedkryzysowym, ale zwłaszcza w następnych latach kryzysu, to jest jasne, że większy wpływ wywierały tu sfery urzędnicze niż środowiska inteligencji skoncentrowane na problemach kultury.

Dorobek inteligencji $\mathrm{w}$ omawianych latach nie może być oceniany tylko z punktu widzenia jego znaczenia dla państwa polskiego. Byłoby to podejście stawiajacce państwo, jego agendy i aparat w centrum perspektywy historycznej, wyraz jakiejś statolatrii, ubóstwienia państwa, którego rzecznikiem najczęściej bywa władza. Zależność bywa natomiast odwrotna, państwo trzyma się mocno, gdy mocno trzyma się naród, a naród jest silny, gdy silna jest kultura narodowa, stanowiąca jego spoiwo. Sprawy te interesują nas w kontekście prac i osiagnięć inteligencji. Przyczyniła się ona w wielkim stopniu do nadania państwu i jego organom (łącznie $\mathrm{z}$ administracja, armia, wymiarem sprawiedliwości itd.) wstępnego kształtu, niezbędnego do zlepienia Polski z kawałków porozbiorowych.

${ }_{11}$ Zob. téz J. Żarnowski, Rola państwa w kształtowaniu społeczeństwa Polski międzywojennej. Zarys problemu i uwagi wstepne, w: Państwo i społeczeństwo Drugiej Rzeczypospolitej. Zbiór studiów, red. J. Żarnowski, Warszawa 2014 (Metamorfozy Społeczne, 8), s. 9-32. 
Po kilku latach nadszedł czas nowych koncepcji i reform, które zostały przez rządzaca grupę skierowane raczej w nurt autorytaryzmu, ale przynajmniej początkowo z utrzymaniem oficjalnie ideologii równościowej i przyjętych przed $1914 \mathrm{r}$. niektórych haseł demokratycznych. I tak np. wymiar sprawiedliwości został częściowo ujednolicony z uwzględnieniem nowych idei, zrodzonych z ideałów humanitarnych i z osiagnięć ówczesnej socjologii i psychologii społecznej ${ }^{12}$.

Choć niszczaccy kryzys gospodarczy, który wybuchł po kolejnych kilku latach, zupełnie temu nie sprzyjał, podjęto prace nad upowszechnieniem nowoczesnych instytucji pomocy społecznej, ubezpieczenia i zabezpieczenia społecznego. Podjęto z jednej strony pracę nad podniesieniem poziomu oświaty powszechnej i ograniczeniem analfabetyzmu, z drugiej zaś nad nowoczesnym, demokratycznie usytuowanym szkolnictwem średnim (nie w pełni się to udało), a także nad pomnożeniem i rozbudową szkół wyższych (w tym stworzono trzy nowe uniwersytety państwowe, jeden z nich - w Warszawie - powstał jeszcze w czasie wojny 1914-1918). Pojawiły się liczne instytucje kultury, w tym muzea, a jedna z instytucji kultury było Polskie Radio, które od zera rozwinęło się w ciagu 12-13 lat do poziomu ważkiego przekaźnika informacji i kultury, na stałe docierającego do kilku milionów odbiorców ${ }^{13}$. Pewne osiagnięcia komunikacji kolejowej, wprowadzenie komunikacji lotniczej, udoskonalenie sieci telefonicznej i telegraficznej, instalacja gospodarki morskiej na niewielkim odzyskanym skrawku wybrzeża - to wszystko należało także do osiagnięć nie tylko gospodarki, ale i kultury polskiej, podobnie jak rozwój budownictwa monumentalnego i mieszkaniowego. Wyobraźnia społeczna narzucała konieczność modernizacji, nowoczesności, której powinna podlegać gospodarka, życie codzienne, ideologia, państwo i jego agendy z armią włącznie. Oczywiście należy przede wszystkim przypomnieć rozwój twórczości artystycznej - od literackiej do plastycznej, w tym architektury, muzyki, a także sztuki stosowanej, jak wówczas się wyrażano. Tu także powstał obowiązujący wymóg czy hasło nowoczesności.

12 Zob. najnowszą pracę traktującą m.in. o przestępcach i więziennictwie: M. Rodak, Pospolitacy, cuwaksi, powrotowcy. Osadzeni w Więzieniu Karnym Warszawa-Mokotów (1918-1939), Warszawa 2017.

${ }^{13}$ Ok. 6 mln stale słuchało radia, trzeba też pamiętać o mniej lub bardziej zorganizowanym słuchaniu zbiorowym; zob. J. Żarnowski, Polska 1918-1939: praca, technika, społeczeństwo, Warszawa 1999, s. 324. Tamże bliższe informacje o poziomie technicznym gospodarki i infrastruktury Polski, w tym o środkach rozpowszechniania informacji, wiedzy i kultury, a więc o mediach, które w znacznej mierze obsługiwały przede wszystkim inteligencję. 
Wszystkie te osiagnięcia trzeba rozważać na tle ówczesnego kształtu i możliwości państwa polskiego, które były określone przez zaszłości historyczne i sytuację międzynarodowa. Kształt granic i skład etniczno-narodowościowy były czynnikami danymi w 1918 r. przez historię i politykę międzynarodowa grupy mocarstw sprzyjających nowej Polsce. Grupa ta jednak niebawem zaczęła tracić swą zwartość, co nie mogło wróżyć dobrze państwu powstałemu pod jej patronatem. Pamiętajmy, że Stany Zjednoczone nie podpisały traktatu wersalskiego, który bez ich udziału w wojnie nie mógłby przecież powstać. W ówczesnej sytuacji wyjątkowo ważna była rola Józefa Piłsudskiego i jego obozu, który faktycznie kierował polityką zagraniczną w sposób niezależny od nadzoru mocarstw, co po jego odejściu nigdy więcej się nie powtórzyło.

Byłoby błędem upatrywać osiagnięcia międzywojennej inteligencji tylko w tym środowisku inteligenckim, o którym szerzej wspominaliśmy, to znaczy związanym z obozem legionowym. Grupy o przeciwnej orientacji wniosły też swój niemały wkład - w walkę o granice i status Polski w czasie konferencji wersalskiej, w integrację b. dzielnicy pruskiej, a także innych obszarów (np. na wschodzie ówczesnej Polski, jak również w b. Galicji). Trzeba więc oddać sprawiedliwość działaczom państwowym, ale także twórcom dorobku materialnego związanym $\mathrm{z}$ tą orientacja. Ich udział w polskiej działalności państwowej, politycznej i kulturalnej był niezbędnym elementem składowym kultury państwowej i intelektualnej, bez niego ówczesna państwowość byłaby zjawiskiem niepełnym, a także niespotykanym na tle międzynarodowym. Wspomniana orientacja wywierała wpływ na sprawy państwowe w okresie przedmajowym, a zwłaszcza w latach 1922-1925.

Trudno też nie wspomnieć o wielostronnej roli Kościoła katolickiego, bez niego również trudno sobie wyobrazić ówczesne życie społeczne, w którym brał on udział od stuleci. Bez tego składnika również i państwowość, i kultura polska były wówczas nie do pomyślenia. Przyrodzona Kościołowi nuta konserwatyzmu wywoływała aprobatę lub protest, zwłaszcza u części inteligencji, bo szersze warstwy ludności polskiej traktowały ja jako odwieczną i naturalną. Liberalna inteligencja była obiektem zdecydowanej krytyki ze strony Kościoła i jego przedstawicieli, nasilającej się z czasem w miarę zmian w orientacji międzynarodowej Stolicy Apostolskiej. Wystarczy przypomnieć krytykę inteligencji jako „straży przedniej komunizmu" ze strony późniejszego prymasa Stefana Wyszyńskiego ${ }^{14}$.

${ }_{14}$ S. Wyszyński, Inteligencja $w$ przedniej straży komunizmu, Katowice 1939. Po 1945 r. nie wykazywano tej pozycji w bibliografii prac kardynała, stąd dziś trudno znaleźć o niej wzmianki nawet w Internecie. 
Pisząc o tych kwestiach, nie można też pominąc katolickiego nurtu inteligenckiego o zdecydowanie elitarnym charakterze, związanego z pismem „Verbum”, podwarszawskimi franciszkańskimi Laskami i ks. Władysławem Korniłowiczem. Był on echem inspiracji francuskich personalistów chrześcijańskich, jak Jacques Maritain, Emmanuel Mounier czy Pierre Teilhard de Chardin. Do personalizmu nawiazywały też niektóre wypowiedzi filozoficzne czy poetyckie Karola Wojtyły z nieco późniejszych lat. Echa tego kierunku myśli katolickiej odegrały znaczna rolę wśród inteligencji następnych pokoleń, w latach 1945-1989.

Wybuch wojny w $1939 \mathrm{r}$. spowodował rozproszenie polskiej warstwy intelektualnej i wykształconej. W części została wypędzona do wyznaczonej przez Niemców strefy w Polsce centralnej (Generalne Gubernatorstwo), w tym znalazła się inteligencja ziem zachodnich wygnana z nowych granic Rzeszy. Na wschodzie polska warstwa intelektualna obudziła się na jesieni 1939 r. pod władzą sowiecka, masowo też była przesiedlana w głąb sowieckiego imperium. Części inteligenckich (i innych) uchodźców udało się przekraść do zachodniej Europy, różne odpryski rozpierzchły się po całym świecie. W wyniku zbrodni i represji niemieckich i sowieckich, w tym w obozach założonych przez jednych i drugich, w czasie działań wojennych na Zachodzie, w Afryce i na Bliskim Wschodzie, walki konspiracyjnej, partyzanckiej i powstania warszawskiego, inteligencja polska (w każdym wymiarze czy definicji) poniosła dotkliwe straty. Rozproszenie osłabiło ja i tym bardziej nie mogła przemawiać jednym głosem.

Mimo wszystko jednak wojenna prolongacja przedwojennego państwa, jak również ruch oporu opierały się właśnie na tej przetrzebionej, rozproszonej i stosunkowo nielicznej elicie intelektualno-społecznej, i to zarówno na emigracji, jak i w podziemnym życiu polityczno-społecznym w okupowanej Polsce. Do inicjatyw powstałych w tym środowisku dołaczyły liczne bez wątpienia grupy ludności chłopskiej, robotniczej, drobnomieszczaństwa, ale zapalnikiem i gronem kierowniczym była, zwłaszcza z początku, inteligencja. Sytuacja ułożyła się tak, że działalność inteligencji, zarówno państwowo-konspiracyjna, jak i oświatowo-konspiracyjna aż do szczebla uniwersyteckiego, wreszcie zabiegi o zachowanie kadr i zasobów sztuki rozwinąć się mogły przede wszystkim na terenie Generalnego Gubernatorstwa. Ale też na tym terenie nastapiła hekatomba powstania warszawskiego i wówczas także inteligencja zorganizowała i podtrzymywała kilkumiesięczna akcję ratunkowa.

Straty, które poniosły inteligencja i warstwa wykształcona, wpłynęły na jej obraz ogólny. Niemcy od pierwszych dni okupacji rozpoczęli 
eksterminację inteligencji ziem zachodnich i działaczy z terenu Warszawy. Mordowanie inteligencji i warstwy aktywnej trwało aż do ostatnich dni okupacji, nawet wtedy, gdy już było słychać działa prowadzące ogień przez Wisłę. Niemcy wymordowali wielu inteligentów pochodzenia żydowskiego, choć sporo twórców i osób z tych środowisk przetrwało. Inteligencja uchodząca na wschód ucierpiała od prześladowań i deportacji sowieckich, a zwłaszcza od zbrodni katyńskiej i podobnych eksterminacji. Podkreślmy raz jeszcze, że zmieniło to wszystko strukturę warstwy wykształconej, choć nie potrafimy dokonać dokładnego bilansu tych zmian.

Koniec wojny zaskoczył Polskę i inteligencję, pozostawiając kraj w sytuacji całkowicie sprzecznej z oczekiwaniami z 1939 r. Dość znaczna część inteligencji znalazła się na Zachodzie. Sporo działaczy i twórców nie wróciło do kraju, tworząc zalążek „londyńskiej” emigracji politycznej. Liczba tych, którzy tam pozostali, nie była wielka na tle ogólnych ubytków społeczeństwa i warstwy wykształconej, ale obejmowała, obok działaczy politycznych, stosunkowo wiele nazwisk znanych intelektualistów. Jednak wielu też pozostało w kraju i wraz z repatriowanymi wkrótce (lub później po kryzysie stalinizmu) ze Wschodu i z Zachodu stworzyli oni znaczące środowisko.

Początkowo znaczna część społeczeństwa i warstwy intelektualnej wierzyła mniej lub bardziej w autonomię Polski i „demokrację ludową, choć inna część sprzeciwiała się nowemu porządkowi, który w pełni popierała tylko część nieznaczna, głównie związana z komunistami. W pierwszym okresie nowy system miał formalnie za sobą wolę Wielkiej Trójki, decydującej o losach świata po pokonaniu Hitlera, przypieczętowaną decyzjami konferencji w Poczdamie (lipiec-sierpień 1945 r.). Przypominano niekiedy półgłosem o zobowiązaniach wojennych zachodnich sojuszników Polski w 1939 r., Francji i Wielkiej Brytanii, co jednak nie zmieniało ich drugoplanowej roli po wojnie.

Zarazem jednak znaczna, pewnie przeważajaca część inteligencji i całej ludności wcale nie chciała przywrócenia reżimu sanacyjnego, o czym dziś się nie wspomina. Ta okoliczność mogła dezorientować wielu zwolenników demokratycznych przemian, o których mówiły deklaracje stronnictw demokratycznych w kraju i zagranica z lat 1944-1945.

Zanim ogłoszono socjalizm na modłę sowiecka, warstwa intelektualna, czyli inteligencja w myśl formuły, którą się tu posługujemy, starała się wznowić swą działalność, odbudować swój byt i swe warsztaty pracy twórczej; osiagnęła wtedy pewne doraźnie pozytywne skutki w odbudowie życia w kraju i odtworzeniu życia kulturalnego, w tym w zagospodarowaniu ziem zachodnich i ich integracji z Polska. Trzeba o tym 
pamiętać, bo wiele z tych wysiłków dało też trwałe rezultaty, ale działo się to wszystko przez bardzo krótki okres ${ }^{15}$. W tych pierwszych latach charakterystyka wspomnianego środowiska inteligenckiego uwzględnić musi hekatombę inteligencji w czasie II wojny światowej i ubytki związane z pozostaniem na emigracji dziesiątków tysięcy niewątpliwych członków warstwy oświeconej. Osoby w kraju aspirujace do uczestnictwa w tym środowisku często mogły w tych niezwyczajnych warunkach powojennych uzyskać stanowiska, stopnie i pozycje droga przyspieszona, co po wojnie było raczej zrozumiałe i nie budziło większych zastrzeżeń ${ }^{16}$. Podobne praktyki nieznacznie złagodziły niedobór kadr $\mathrm{w}$ różnych zawodach $\mathrm{w}$ tych pierwszych miesiącach i latach ${ }^{17}$. Jednak cała sytuacja miała się wkrótce zasadniczo zmienić i te drobne stosunkowo sprawy straciły wszelkie znaczenie.

Już w końcu 1947 r., zgodnie z wytycznymi Stalina, zadeklarowano monopol władzy dla komunistów (choć samego tego terminu unikano!) i przedstawiono program „socjalistycznej przebudowy społecznej” na zasadach zaczerpniętych z ZSRR. W grudniu 1948 r. powstała PZPR i z ta chwila kurs na system komunistyczny stał się obowiąujący. W propagandzie trzymano się zreszta terminu „socjalizm”. Dla inteligencji w znaczeniu tu omawianym była to perspektywa odrzucenia i unicestwienia, bo zupełnie nie pasowała ona do planowanej „przebudowy”. Samodzielna elita intelektualna nie była tu potrzebna i dla rządzącej partii mogła być wyzwaniem. Powstało pytanie, czy nastapi likwidacja tej grupy, jak to było w Rosji, czy też próba jej wykorzystania. Jak $\mathrm{w}$ wielu innych kwestiach, jasna odpowiedź nigdy nie padła. Jednak osłabiony po krytyce stalinizmu reżim nie mógłby sobie pozwolić ani zapewne nie był nawet wówczas $\mathrm{w}$ stanie rozprawić się $\mathrm{z}$ inteligencja.

Środowiska twórcze przeszły we wczesnych latach 50. próbę wprowadzenia „realizmu socjalistycznego”, czyli sowietyzacji sztuki i kultury, która zapamiętały na dziesięciolecia. Ale funkcjonowanie państwa nie było możliwe bez niezbędnej elity intelektualnej, a zastapić ją szybko

15 Ten ważny czas nie znalazł dotąd zadowalającego ujęcia w historiografii, wolnego od stronniczych zniekształceń i całkiem dowolnych twierdzeń; zob. moją recenzję: Uwagi o ksiażce Marcina Zaremby „Wielka Trwoga”. Polska 1944-1947. Ludowa reakcja na kryzys, Kraków 2012, RDSG, t. 73, 2013, s. 275-297.

${ }^{16}$ Wskazują na to np. szczegóły awansów naukowych wybitnych potem historyków w latach 1946-1947.

${ }_{17} \mathrm{~Np}$. aplikanci adwokaccy sprzed wojny mogli zostać łatwo adwokatami, co przed wojną łączyło się z uciążliwą procedurą. Są to moje spostrzeżenia, umożliwione przez możliwość fragmentarycznego obserwowania praktyki sądowej w tych latach. W różnych branżach i instytucjach zastosowano podobne ułatwienia. 
było niepodobieństwem. Do tego wszelkie przyspieszone kursy się nie nadawały. Toteż korzystano $\mathrm{z}$ niej nadal na warunkach narzuconych przez rządzących, licząc, że z czasem wyrośnie własna elita, ewentualnie przy pomocy instytucji takich jak IKKN/INS (ale to dotyczyło tylko nauk społecznych i np. prawników - poprzez Centralną Szkołę Prawniczą im. T. Duracza, choć ta miała raczej charakter doraźnie praktyczny). Tak jak okres „demokracji ludowej” trwał krótko (3-4 lata), tak i stalinowskie porządki w pełnej swej krasie nie trwały wiele dłużej, bo już w latach 1955-1956 były kwestionowane nawet przez część rządzących.

Znaczna, jeśli nie ogromna większość inteligencji w omawianym tu znaczeniu znalazła się w cieniu, zdezorientowana i oporna, choć niewykluczająca udziału w pojedynczych, pozytywnych przedsięwzięciach reżimu, których oczekiwano po wstrzasie z 1956 r. Stanowisko to znalazło potwierdzenie, gdy pojawiły się symptomy kompromitacji i odrzucenia stalinizmu. Od początku jednak reżim partyjny znalazł pewna liczbę zwolenników wśród inteligencji, zwłaszcza wśród przedwojennych sympatyków, o których była wyżej mowa, a także wśród nielicznych w sumie, choć przez chwilę widocznych w ówczesnym krajobrazie grup czy grupek najmłodszego pokolenia, podatnego na nieznane mu dotąd hasła radykalno-lewicowe. Dla tych grup owa komunistyczna wiosna ideologiczna oznaczała wybór, którego zapewne większość potem żałowała, ale w realnym przebiegu historycznym nie miało to już żadnego znaczenia. Niektórzy szczególnie aktywni wówczas w lansowaniu sowieckich nowości okazali się po latach równie aktywni w odrzucaniu i gromieniu ich resztek.

Po 1956 r. sytuacja polityczna ustabilizowała się na dłużej. Wymienione wyżej i podobne instytucje mające wykształcić kadry rozsypały się lub zmieniły charakter. Zapowiedzi polityczne dotyczące „socjalistycznej przebudowy", ogłoszone w 1948 r., nie zostały odwołane, ale ich realizacja postępowała wolniej lub nawet bywała odcinkowo wstrzymywana, jak program „socjalistycznej” przebudowy rolnictwa. Rządzący musieli przyjąć do wiadomości, że elita intelektualna i jej otoczenie - tak rozumiem kategorię inteligencji w ramach omawianej obecnie definicji - nie da się szybko zreformować w myśl zasad sowieckiego komunizmu, ale na dłuższą metę dążyli do jej podporządkowania „socjalizmowi”, tj. władzy partii. Młode pokolenie, które w założeniach miało być głównie „robotniczo-chłopskim", szkolono według nowych dogmatów, w nadziei uzyskania dopływu do warstwy wykształconej, do inteligencji. Rezultaty tej polityki były jednak mierne. Kompromitacja stalinizmu oddziałała na kolejne kilka pokoleń, które w swej masie sceptycznie przyjmowały nieco przekształcone po 1956 r. zasady nowego społeczeństwa i nie 
chciały identyfikować się z partią. Narybek „klasowo właściwy” nie zasilił warstwy kulturotwórczej, na którą system miał, mimo wszystko, ograniczony wpływ.

Trzeba zauważyć, że inteligencja jako środowisko aktywne kulturalnie kształtowała się w znacznym stopniu inaczej niż wspomniana wyżej warstwa inteligencji zawodowej. Z natury rzeczy większą rolę $\mathrm{w}$ tym środowisku odgrywały, zwłaszcza na początku, środowiska i rodziny już uprzednio należące do warstwy kulturotwórczej, a operacje i dyrektywy rządzącej partii miały tu utrudniony dostęp, z wyjątkiem niewielkiego grona przekonanych. Wielki rozwój liczebny warstwy wykształconej, nowo rekrutowanej w tych latach i później z rodzin nienależących uprzednio do inteligencji, na ogół najwcześniej w drugim pokoleniu mógł odbić się na inteligencji jako warstwie kulturotwórczej. Dopływ do tej warstwy odbywał się, jak się wydaje, głównie pod wpływem tradycyjnych środowisk inteligenckich. Szczegółowa analiza tej kwestii byłaby bardzo interesująca, na razie autor musi zaryzykować własne, zapewne ułomne oceny, które należałoby potwierdzić.

Najtrudniejszym zagadnieniem wydaje mi się odtworzenie źródeł rekrutacji kolejnych pokoleń do inteligencji - środowiska decydującego o kształcie kultury narodowej. Bo jednak zmiany w kształtowaniu się podstawowych kategorii, z których rekrutowała się inteligencja w nakreślonym wyżej znaczeniu, nie mogły pozostać bez wpływu na charakter i oblicze całego środowiska. Istotna kwestią jest przyrost liczebny inteligencji we wszelkich znaczeniach tego terminu. W ciagu dziesięcioleci liczebność poszczególnych zawodów i środowisk inteligenckich, w tym także zawodowych artystów i twórców, literatów, dziennikarzy, artystów plastyków, muzyków, a także uczonych wszelkiego rodzaju i wszystkich stopni, znacznie się zwiększyła. Nie próbujemy nawet żadnych obliczeń, bo też nie tędy droga. Możemy przyjąć za pewnik, że inteligencja - środowisko kultury - pomnożyła liczbę swych adeptów. Ta informacja sama przez się jest mało interesująca, ważniejsze byłoby ustalenie, czy omawiane środowisko funkcjonowało jakoś inaczej niż przed wojną czy w latach 40.-50. Jest bardzo prawdopodobne, że nasycenie społeczeństwa inteligencją jako warstwą tworzącą kulturę narodowa, a zarazem uczestniczącą w wieloraki sposób w bieżącym życiu kraju stawało się wówczas wyższe niż dawniej, przed wojna czy w pierwszych latach powojennych. Musiało to wywrzeć jakiś wpływ na życie społeczne, pytanie, czy przede wszystkim na kulturę i poglądy inteligencji, czy też na działania i sposób funkcjonowania warstwy rządzącej. A może na jedno i na drugie?

Powstały jednak, z drugiej strony, mechanizmy i objawy przystosowania się większości dotychczasowej warstwy intelektualnej do oczekiwań 
władz, przynajmniej w pewnym zakresie. Te mechanizmy zaczęły się oczywiście kształtować zaraz po 1945 r., ale po przełomie 1947 i 1948 r. nabrały nowego charakteru. Sytuacja znów zmieniła się po 1956 r., o czym będzie mowa niżej. Nie brakowało też jednostek i środowisk wyraźnie opornych, ich aktywność podsycały periodyczne kryzysy polityczne, wynikające też z ekonomicznej niewydolności systemu. W pewnych okresach sprzeciw osiagał poziom zauważalny dla całego społeczeństwa, a nawet zewnętrznego świata, zwłaszcza pod koniec całego okresu, w innych był bezpośrednio mniej widoczny (np. na poczatku epoki Gierka).

Spuścizna przedwojennych podziałów i orientacji nie zanikła, ale stawała się coraz mniej istotna, najbardziej kultywowano ją zagranica, wśród pogrobowców Polski międzywojennej. W kraju pojawiły się pod powierzchnią oficjalnego wykoślawionego życia ideologicznego jakby nowe orientacje, ale znacznie luźniejsze i nie tak konkurencyjne jak kiedyś: jedna dopuszczająca wśród motywów ideologicznych ewentualnych zmian socjalizm (np. „prawdziwy socjalizm” czy „demokratyczny socjalizm” w odróżnieniu od oficjalnej ideologii i frazeologii), druga zaś chętniej powołująca się na tradycję i Kościół ${ }^{18}$. To wszystko uległo zmianie, czy przyćmieniu, gdy na horyzoncie w latach 80 . ukazały się perspektywy wejścia Polski bezpośrednio do zachodniego „wolnego świata” kapitalistycznego.

W odpowiednim miejscu wskazano, że inteligencja - środowisko kultury - posiadała swe organizacje zawodowe, kulturalne, profesjonalno-korporacyjne itd., co dopełnia charakterystyki odpowiedniej grupy społecznej. Przed wojną organizacje te pozostawały nieraz pod wpływem i kontrolą władz, ale ogólnie rzecz biorąc istniała możliwość organizowania się przez inteligencję $\mathrm{w}$ różnorakich wymiarach. Zmiana sytuacji już nie po 1947 r., gdy nie było mowy o takim organizowaniu się, ale i po 1956 r. polegała na tym, że wszelkie tego typu organizacje, jak i w ogóle wszelkie organizacje czy to profesjonalne, czy kulturalne i wszelkie inne, musiały być zatwierdzone i sterowane przez partię, przez jej zaufanych ludzi, co na ogół uniemożliwiało albo mocno ograniczało swobodne działanie. Nie wszędzie takie sterowanie było skuteczne, zwłaszcza pod koniec PRL, ale trzeba tu zanotować zasadniczą zmianę $\mathrm{w}$ tym zakresie $\mathrm{w}$ stosunku do czasów przedwojennych, choć i wówczas, za rządów sanacji, swoboda organizowania się bywała

${ }^{18} \mathrm{~W}$ nieco innej płaszczyźnie funkcjonowały też orientacje rodem jeszcze z XIX w., które można określić jako pozytywistyczna i „czerwona” (w znaczeniu podziałów z okresu powstania styczniowego i później). W tym kontekście ciekawa jest korespondencja Stefana Kieniewicza i Henryka Wereszyckiego z lat 1947-1990: Stefan Kieniewicz-Henryk Wereszycki. Korespondencja 1947-1990, wyd. E. Orman, Kraków 2013. 
ograniczana. Oczywiście władze musiały bardziej liczyć się z grupami intelektualistów, często o ponadnarodowej renomie, niż z mniej znanymi i mniej utytułowanymi środowiskami. Te mniej utytułowane środowiska były jednak liczniejsze i przez to decydowały o funkcjonowaniu różnych części aparatu państwowego, społecznego, gospodarczego, oświatowego itd., itp., co w momentach nadzwyczajnych mogło mieć duże znaczenie.

Czynnikiem istotnym w stosunkach władzy i inteligencji był rozpoczęty tuż po śmierci Stalina proces kruszenia się ideologii marksizmu-leninizmu. Nie miała ona siły przyciagajacej i kłóciła się z rzeczywistością krajową i międzynarodowa. Stopniowo także rządzące kręgi partii przestały ja traktować poważnie, zwłaszcza ich młodsze pokolenie, które po 1956, 1970 i w późniejszych latach zajęło miejsce przedwojennych komunistów. Z dawniej fanatycznie wyznawanej ideologii zamieniła się ona w katalog posunięć obliczonych na utrzymanie władzy aktualnej warstwy rządzącej, która musiała się trzymać uświęconej frazeologii oraz liczyć się z miejscem Polski w bloku sowieckim, ale z drugiej strony także z naciskiem szerokich mas ludności, wyrażonym w masowych wystapieniach w 1956 r., a potem w czasie kryzysu w 1970, 1976 r. i w latach 80.

Byłoby jednak naiwnością sądzić, że różne fragmenty tego rozbitego przez rzeczywistość systemu ideologicznego nie miały żadnego wpływu na świadomość inteligencji. Pomijając bezpośrednich wyznawców ideologii partyjnej, których zresztą nie brakowało, wiele cząstkowych poglądów czy tez, czy choćby przyzwyczajeń terminologiczno-ideologicznych, pozostało trwale w pamięci nie tylko pokoleń masowo kształconych w szkołach od podstawowych do wyższych, ale także inteligentów w omawianym tu znaczeniu.

Wydarzenia $1968 \mathrm{r}$. zahaczyły poważnie o inteligencję w obecnie omawianym rozumieniu. Mam na myśli rozgrywki wewnattrzpartyjne związane z próbą przechwycenia władzy przez grupę młodszych przywódców PZPR, z wykorzystaniem haseł brzmiących „,narodowo”, skontrastowanych z dotychczasowym „internacjonalizmem”. Ofiara padli Żydzi i ludzie pochodzenia żydowskiego, których łatwo było oskarżyć o sprzyjanie wojnie sześciodniowej z 1967 r. i wezwać czy zmusić do emigracji. Spowodowało to exodus pewnej liczby osób pochodzenia żydowskiego, w większości należących do inteligencji lub do elity partyjnej. Dariusz Stola ocenia ich liczbę na prawie 13 tys. ${ }^{19}$ Wśród nich znaleźli

${ }_{19}$ D. Stola, Kraj bez wyjścia? Migracje z Polski 1949-1989, Warszawa 2010, s. 222. Autor szeroko opisuje organizowanie tej kampanii przez władze, UB itd. Nie wspomina zupełnie o postawach szerszych kół społeczeństwa. 
się naukowcy, literaci, dziennikarze, obok byłych pracowników aparatu partyjnego, UB, wojska. Inna pochodna tych wydarzeń, a nawet szerzej, tendencji „narodowej” w aparacie partyjnym, zwłaszcza młodszego pokolenia, było „unarodowienie” oficjalnej propagandy i frazeologii przy osłabieniu frazeologii ,internacjonalistycznej”. Miało to pewien wpływ na publicystykę i język polityczny, tym bardziej że raz wprowadzone już nie bardzo mogło być cofnięte.

Do partii należały miliony, w tym setki tysięcy inteligentów. Powstało nigdzie niesformułowane, lecz zrozumiałe dla bardzo wielu dążenie, by zapewnić krajowi w miarę spokojny byt i pomyślność wewnątrz bloku sowieckiego, póki istnieć będzie dwubiegunowy system bloków. A funkcjonowanie tego dwubiegunowego świata, jak się wydawało, miało przed soba jeszcze cała epokę. Na całym świecie uważano tak nawet w przeddzień kryzysu lat 1989-1990. Na tej płaszczyźnie starało się działać wiele środowisk, zwłaszcza inteligenckich, przy czym najczęściej przystosowanie łączyło się z utrzymaniem i w miarę możności obroną podstawowych standardów wynikajacych z tradycji i przynależności kulturowej Polski, które, nazwane czy nienazwane, oddziaływały na świadomość inteligencji. Nie eksponowano zbytnio np. przynależności Polski do kultury europejskiej, ale dosłownie nikt nie mówił o przynależności naszego kraju czy to do jakiejś kultury azjatyckiej (euroazjatyckiej?), czy „wschodniej”. Takie sformułowanie oznaczałoby samobójstwo jego autora.

Ta sytuacja z konieczności zakładała współpracę z istniejącym systemem, bez czego nie było możliwe funkcjonowanie jednostek i rodzin, a tym bardziej żadne działanie pozytywne. Większość inteligencji (i przecież nie tylko inteligencji) musiała patrzeć na sytuację w Polsce i na świecie od wewnątrz systemu, co powodowało pewien stopień domyślnej legalizacji istniejącego państwa, dla którego nie było wówczas alternatywy. To prowadziło do konfrontacji inteligentów z kraju np. z przedstawicielami „londyńskiej” emigracji, odrzucającej praktycznie jakiekolwiek zmiany w kraju (ale nie z emigracja spod znaku paryskiej „Kultury”), gdy gdzieś poza Polską takie rozmowy były możliwe. Sam zresztą takie rozmowy i opowiadania o nich pamiętam $\mathrm{z}$ lat 60 . Zmiany $\mathrm{w}$ tej mierze zachodziły, gdy kryzys całego systemu sowieckiego i sytuacja jego satelitów ujawniły się wyraźnie. Sądzę, że dzisiaj sprawy te nie zawsze sa oświetlane zgodnie z prawda, poza tym coraz mniejsza liczba świadków pamięta rzeczywistość sprzed 30-40 lat i więcej, we współczesnych tekstach zastępowaną nieraz własnymi wyobrażeniami, zapłodnionymi przez schematyczne obrazy noszace piętno propagandy.

Byli i wyznawcy urzędowej polityki, związani tak czy inaczej z warstwą rządząca, ale $\mathrm{w}$ niezbyt imponującej liczbie. W razie czego mogli 
zapewnić rządzącej partii jaką taką fachowa ekspertyzę. Nie brakło zainteresowanych wyłącznie własną kariera, a także uzyskujących korzyści ze współpracy z władzami. Byli także ci, którzy nastawiali się na starcie $\mathrm{z}$ istniejącym reżimem, nie było ich wielu, początkowo (po 1956 r.) stanowili wyjątek, ale ich liczba z czasem rosła, zwłaszcza po kolejnych kryzysach politycznych.

Trudno mówić o świadomej, przemyślanej taktyce tych środowisk inteligenckich, które kierowały się, bardziej niż buntem, raczej naturalnym na gruncie odziedziczonej kultury i tradycji dazżeniem do utrzymania kontaktu z kultura światowa, co w latach murów, ograniczeń i preferencji dla obozu socjalistycznego nie było takie proste. Kontakty z kultura światową utrzymywały w różny sposób i rozmaitymi kanałami zarówno środowiska naukowe, jak i artystyczne, a także przedstawiciele zawodów praktycznych, technicznych i ekonomicznych, wreszcie ludzie, którzy w najrozmaitszy sposób załatwiali sobie pracę i pobyty, zwłaszcza w USA i w zachodniej Europie. Kontakty te niekoniecznie miały posmak polityczno-opozycyjny. Część tej współpracy była zgodna z urzędowymi planami kooperacji naukowej czy artystycznej albo gospodarczej i technicznej, ale wraz z postępującą degradacją systemu często spontanicznie nabierały takiego charakteru. Samo obcowanie z bieżąca kultura naukową i artystyczna, nie mówiąc już o bieżącym życiu politycznym Zachodu, pozostawało na długo w pamięci. W późniejszych latach ścisłe początkowo ograniczenia zelżały i setki tysięcy inteligentów znalazły się wśród milionów, które przez jakiś czas w tych latach przebywały na Zachodzie w celach handlowo-turystycznych albo jako siła robocza, ale też nieraz jako wykwalifikowani pracownicy naukowi i techniczni, jedni w ramach wymiany, inni na zasadzie indywidualnej, nie wyłączajac „odmowy powrotu” z wyjazdu czy delegacji ${ }^{20}$.

Koła naukowe i artystyczne przyswoiły wówczas polskiej kulturze wiele osiagnięć i dokonań nauki i kultury zachodniej, i trzeba pamiętać, że to nie stało się „samo”, lecz głównie za pośrednictwem polskiej inteligencji. Osiagnięcia kultury polskiej, w tym literatury i sztuki, sztuk plastycznych i muzyki, jak również filmu, teatru, grafiki i plakatu, były

20 Tylko w latach 1981-1989 do krajów kapitalistycznych wyjechało prawie $11 \mathrm{mln}$ mieszkańców PRL, z czego nie powróciło (na czas, tj. w czasie ważności wizy wyjazdowej) trochę ponad milion, a powróciło prawie $10 \mathrm{mln}$; zob. D. Stola, dz. cyt., s. 490. Na tle tych liczb tytuł cytowanej książki można by potraktować jako dowcip. W poprzedniej dekadzie (1971-1980) wyjazdy prywatne i turystyczne do krajów kapitalistycznych liczono od 100 tys. do prawie 500 tys. rocznie; tamże, s. 486-487. Przed wojną wyjazdy za granicę, ale poza emigracją stałą czy sezonowa, obejmowały kilkadziesiąt tysięcy osób rocznie; zob. „Mały Rocznik Statystyczny” 1938, s. 58; 1939, s. 56. 
tė imponujące, a ich dystrybucja społeczna w kraju i zagranica znacznie szersza niż przed wojną. Dzięki temu po przełomie 1989 r. Polska w naturalny sposób mogła dołączyć do „Europy” i ówczesnego wolnorynkowego świata, i nie musiała uczyć się wszystkiego od nowa w dziedzinie polityki, prawa, a nawet gospodarki i techniki.

Po upadku stalinizmu rządzące koła partyjne musiały w znacznym stopniu dostosować się do powszechnych trendów gospodarczych i technicznych, to samo musiał uczynić ZSRR, jeśli nie chciał pozostać na niebezpiecznym marginesie $\mathrm{w}$ rozwoju gospodarczym i technicznym. Te niezbędne procesy dostosowawcze i odpowiednie zabiegi w zakresie planowania i wykorzystania nowej techniki płynącej z Zachodu musiały być dokonywane $\mathrm{z}$ wykorzystaniem kadr inteligenckich, bez których nawet zwykłe utrzymanie funkcjonowania gospodarki byłoby niemożliwe. W takim znaczeniu inteligencja czy jej poszczególne środowiska wywierały jakiś wpływ na kształt polityki, np. wymiany handlowej i technicznej z zagranica, planowanie inwestycji (zwłaszcza tych niemajacych charakteru ideologicznego) itd., itp. Gdzie w grę wchodziła ideologia, czy to, co z niej pozostało, czyli interesy obozu socjalistycznego, a zwłaszcza ZSRR, jak również rządzącej w Polsce warstwy, tam opinie specjalistów lekceważono, zresztą w takich (i w podobnych) wypadkach partia, jak już wspomniano, miała do dyspozycji „swoich”, bliskich sobie specjalistów, często o nabytym pewnym autorytecie, niepodobnych już do „fachowców” po przyspieszonych kursach z lat 40.-50., ale związanych z aparatem partyjnym lub odpowiednio „spolegliwych”. Trudno zaprzeczyć, że i oni, albo przynajmniej niektórzy z nich, należeli do omawianej przez nas kategorii inteligencji. Niestety to właśnie oni opiniowali programy w stylu Huty Katowice, nastawione na górnictwo i przemysł ciężki, gdy społeczeństwo i gospodarka potrzebowały zupełnie innych kierunków rozwoju, nastawionych na zaspokajanie szerokich potrzeb społecznych.

Omawiając inteligencję okresu międzywojennego, naszkicowałem w kilku zdaniach przynajmniej ważniejsze wyniki jej pracy i osiagnięcia. W stosunku do Polski powojennej nie będzie można łatwo, a może wcale nie będzie można oddzielić prawdziwych rezultatów jej pracy od działań narzuconych i kontrolowanych odgórnie. Ale przecież w tych ostatnich bywały elementy pozytywne na miarę ówczesnych warunków. Mam na myśli programy rozwojowe, skażone służebnościami na rzecz komunistycznej i radzieckiej/rosyjskiej dominacji. Jeśli zwrócimy się ku takim problemom jak rozwój oświaty i szkolnictwa, budownictwo mieszkaniowe, industrializacja jako całość (ale z wyjątkami!), wprowadzanie (o tyle o ile) nowocześniejszej techniki, funkcjonowanie służby zdrowia i nowe 
kształty medycyny - wszędzie znajdziemy pozytywny udział polskiej inteligencji. Rzecz w tym, że wyodrębnienie go od działania organów i instytucji państwowych nie jest łatwe. A tymi ostatnimi kierowała partia.

Mniejsze problemy nastręcza bezpośrednia twórczość artystyczna, jej upowszechnienie oraz w ogóle krzewienie kultury wyższej. Oczywiście wiąża się z tym kwestie kontroli przez władzę upowszechniania tekstów kultury. Taka kontrola istnieje zawsze, ale jej skala bywa przecież różna. W okresie Polski Ludowej władza pretendowała do roli „wychowawcy" społeczeństwa, arogowała więc sobie prawo do wyboru treści kulturowych, które można czy należy upowszechniać. Na szczęście władzy na ogół tylko wydaje się, że jest wszechwładna, toteż bardzo wiele nowych treści kulturowych z dziedziny literatury, filmu, sztuk plastycznych, a także badań naukowych z zakresu humanistyki, nauk społecznych, filozofii, metodologii nauk inteligencja potrafiła sobie przyswoić oraz w takiej lub innej formie przekazać społeczeństwu.

Była już wyżej mowa o praktycznej niemożności sformułowania obiektywnej oceny przewagi tej czy innej orientacji światopoglądowej, ideologicznej, politycznej wśród inteligencji po I wojnie światowej. Tym bardziej odnosi się to do epoki powojennej (tj. po 1945 r.). Przez bez mała pół wieku Polski Ludowej nie było wolnych wyborów na żadnym szczeblu. Wspomniałem, że nie brakowało współpracujacych z partia czy kierowanym przez nia państwem, ale czy to wystarczy, by ocenić przekonania? Pamiętajmy zaś, że chodzi tu - w myśl przytoczonej definicji - o środowisko aktywne kulturalnie, a w mniejszym stopniu politycznie. Przy tym środowisko to także ulegało zmianom samoistnie, a również pod wpływem bodźców płynących od podobnych środowisk z zagranicy czy od ogólnoświatowych trendów ideowych, światopoglądowych i artystycznych, a nawet od upowszechniajacych się nowych standardów technicznych w dziedzinie komunikacji społecznej, a także w zwykłej komunikacji. Orientacje światopoglądowe i wszelkie inne inteligencji w kraju w latach 80. różniły się znacznie od orientacji z lat 50. Tak przynajmniej mi się wydaje, bo w tej kwestii nie ma i nie będzie twardych danych. Na tym etapie rozważań nie możemy sformułować zdecydowanych sądów w tych kwestiach.

Rozważania te można by snuć bez końca, w tym miejscu musimy więc przerwać, nie możemy bowiem w ramach artykułu rozwinąć szczegółowo kwestii osiagnięć inteligencji w życiu publicznym, społecznym, gospodarczym i artystycznym Polski w latach 1945-1989. Taki temat wymagałby po pierwsze wyjaśnień co do zakresu i kryteriów, po drugie zaś dłuższej pracy i analiz. Myślę jednak, że przedstawiono tu główne kierunki przemian, tak jak wyobraża je sobie autor. 
Poza nadziejami na przeciagnięcie na stronę władzy zwłaszcza młodszych pokoleń, rządząca partia naciskała na warstwę wykształcona w kierunku „modernizacji”. Pod ta nazwa należy rozumieć przeobrażenia zgodne z nieco nowocześniejszym modelem warstwy wykształconej, która zmienia się w krajach rozwiniętych stosownie do przemian ekonomiczno-społecznych. Ale przynajmniej w tym samym stopniu chodziło o swoista technicyzację inteligencji, pozbawienie jej polityczno-ideowego bagażu, osłabienie wpływu i udziału humanistyki, niepewnej politycznie, a zastępowanej przez różne wersje nauk politycznych, marksizmu-leninizmu (później unikano tej nazwy), wydziałów i instytutów dziennikarstwa i nauk politycznych, różnych branżowych ekonomik albo wreszcie placówek politologicznych i historycznych „polsko-radzieckich” i podobnych (np. dotyczących obozu socjalistycznego), nie mówiąc już o wyższych studiach partyjnych, wojskowych i w ogóle mundurowych. Wydaje się, że ta polityka przyniosła wymierne szkody inteligencji pojętej jako elita intelektualna społeczeństwa, a w rezultacie całemu społeczeństwu. Pozostawiła za sobą dość liczną kategorię posiadaczy dyplomów dostosowanych raczej do potrzeb partyjno-państwowych niż do rzeczywistych potrzeb społeczno-kulturalnych. Spostrzeżenie to wymaga dyskusji, choć dziś można by to wszystko określić jako les neiges d'antan - niegdysiejsze śniegi. Co prawda można by też się zastanowić, czy obecne nauki polityczne i podobne nie odziedziczyły czegoś z tamtych schematów.

Omawiając losy inteligencji w okresie międzywojennym, wspominałem o roli Kościoła. Tym bardziej nie można tej kwestii pominąć w odniesieniu do Polski Ludowej. Poczynając od początku „socjalistycznej przebudowy” około lat 1947-1948, Kościół był traktowany przez władzę jako wróg polityczny, a w późniejszym, poststalinowskim okresie jako przeciwnik, którego trzeba tolerować, ale stosując szykany, ograniczenia, utrudnienia wszelkiego rodzaju działalności. Pomijam tu incydentalne właściwie poparcie Gomułki tuż po jego powrocie do władzy (wybory do Sejmu w 1957 r. $)^{21}$. Z przeobrażeń w późniejszych latach skorzystał m.in. Kościół katolicki, którego wpływ, zwłaszcza na młode pokolenia, jak można sądzić, rozszerzył się w latach 60. i 70. Dopiero w ostatnich latach czy miesiącach przed zmianą systemu Kościół stał się pośrednikiem, mediatorem, a nawet gwarantem wymuszonych porozumień. Do tego jednak przede wszystkim przyczynił się wybór Karola Wojtyły na papieża w 1978 r., co spowodowało ogromny wzrost autorytetu

${ }^{21}$ Warto przeczytać, jak pisze o tym bliski instytucjom kościelnym Jan Żaryn, Dzieje Kościoła katolickiego w Polsce (1944-1989), Warszawa 2003, s. 166. 
Kościoła w ówczesnej Polsce, a z czym musiała się liczyć ówczesna słabnąca władza. Interesuje nas ta sytuacja ze względu na stosunki między państwem, Kościołem a inteligencja.

Przez długi okres dzielący lata 1956 i 1989 Kościół był ośrodkiem szerokich ruchów wśród inteligencji, o zasięgu i znaczeniu nieporównanie szerszym niż w latach 1918-1939. Zestawienie stosunku Kościoła do inteligencji, a inteligencji wobec Kościoła kierowanego przez prymasa Wyszyńskiego, autora cytowanej wyżej książki o inteligencji z 1939 r., mówi samo za siebie. Partyjno-państwowe ograniczenia przekornie dodatkowo zachęcały uczestników organizowanych w cieniu Kościoła ruchów, imprez i wystapień, czytelników krępowanej prasy katolickiej czy jeszcze bardziej ograniczanych zgrupowań młodzieżowych. Polityka ograniczeń i represji przyniosła „na odcinku inteligencji” skutki odwrotne do założonych. Widać to także w niektórych rodzajach twórczości, jak literatura czy muzyka. Jakie znaczenie dla kultury polskiej miały te zjawiska, to problem dla obecnych i przyszłych historyków kultury.

Przekształcenia kulturowo-społeczne, w dużym stopniu analogiczne do tendencji ogólnoświatowych, częstsze podróże zagraniczne, film i poczatki rewolucji informatycznej powodowały coraz bardziej bezpośrednią konfrontację zjawisk społecznych i poziomu życia w skali międzynarodowej, toteż nadzieje władz, że młodsze pokolenia będą bardziej spolegliwe wobec istniejącego systemu, umocowanego w ramach bloku kierowanego przez ZSRR, okazały się całkowicie bezpodstawne. Młodsze pokolenie, które samo nie zetknęło się bezpośrednio z terrorem stalinowskim, nawet $\mathrm{w}$ jego polskiej, złagodzonej odmianie, zajęło postawę krytyczna, bardziej zaznaczoną niż u starszych pokoleń. Ta sytuacja, wywołana przez nieuchronne upowszechnienie wykształcenia na wyższym szczeblu i awans kulturalny coraz szerszych środowisk oraz początki globalizacji była podłożem narastającej kontestacji ze strony młodszej części nowej elity intelektualnej, urodzonej po 1956 r. i później. Oczywiście to ogólne twierdzenie nie kwestionuje posiadania nadal przez partię swoich i to bardzo znacznych pozycji w łonie inteligencji, ale podkreślić trzeba pogarszanie się sprawności ekonomicznej i politycznej całego systemu, co podmywało w coraz wyższym stopniu także te pozycje, aż doszło do buntu na początku lat 80., zapoczątkowanego przez ośrodki robotnicze, z dołączeniem się opozycyjnych inteligentów, a potem prawie całej inteligencji.

W końcowych dziesięcioleciach przed zaburzeniami początku lat 80 . nastapił kryzys uprzedniej taktyki środowisk inteligenckich $\mathrm{w}$ stosunku do instytucji państwowych, a właściwie zgodnie z ówczesną retoryka, partyjno-państwowych, która starałem się nakreślić wyżej. Okazało 
się, że istniejący reżim nie daje sobie rady z podstawowymi potrzebami społeczeństwa i gospodarki, jakkolwiek inteligencja chciałaby mu w tym pomóc. Przy tym wielką rolę odegrały miliony osób wyjeżdżających za granicę w kierunku zachodnim i w ogromnej większości powracajace po pewnym czasie. Doświadczenia zagraniczne stały się już nie osiagnnięciem nielicznych, ale doświadczeniem w miarę powszechnym, a tej właśnie konfrontacji system komunistyczny absolutnie nie mógł wytrzymać. To musiało odbić się na środowiskach inteligenckich w zakresie światopoglądowym i na polu planowania własnej przyszłości jednostek i rodzin.

Pewne jest więc, że przemiany społeczno-oświatowe i narastanie nowych środowisk wykształconych musiały wywrzeć wpływ na elitę intelektualna. Ewolucja społeczeństwa wynikała przede wszystkim z potrzeb społeczno-gospodarczych wywołanych przez światowy rozwój społeczeństw przemysłowych oraz przez rewolucję techniczna. Partia starała się ją skanalizować w dogodnym dla siebie kierunku. W obliczu dążeń poszczególnych grup i środowisk społecznych elity intelektualne stanęły między polityką partii, która kiedyś obiecywała przebudować społeczeństwo, teraz zaś coraz bardziej skupiała się na zachowaniu władzy - a coraz bardziej pilnymi potrzebami utrzymania Polski w gronie krajów rozwijających się społecznie i gospodarczo. Chodziło o uniknięcie permanentnego kryzysu, mogącego doprowadzić do degradacji kraju i społeczeństwa poniżej poziomu odpowiedniego dla europejskiego państwa w drugiej połowie XX w.

Zmierzch bloku sowieckiego i widoczne zmiany w równowadze sił pod koniec tego okresu ożywiły nadzieje i konflikty, i wreszcie spowodowały powstanie prawdziwego, w końcu jawnego bloku opozycyjnego. Dołączyło do niego bardzo wielu z dotychczasowych partnerów władz partyjno-państwowych. Po wydarzeniach lat 1980-1982 sytuacja nie mogła już powrócić do dawnego układu. Pojawiły się realne perspektywy usunięcia rządów partii w Polsce, które wpłynęły na postawę przeważającej części inteligencji. Zakończyły się rachuby na ewolucję systemu pod wpływem inteligencji czy Kościoła. Współpracę i oddziaływanie na reżim zastapił opór z celem zmiany samego reżimu. Następne lata były dla inteligencji - elity, podobnie jak i dla całego kraju, latami przejściowymi do nowego etapu, który rozpoczą się wraz z wycofaniem się ZSRR/Rosji z Europy Środkowej i umożliwioną tym zmianą ustroju.

Pisząc o czasach, które nastapiły po odzyskaniu niepodległości w 1918 r. i w kilku następnych latach, wspominałem o wyjątkowej roli inteligencji w znaczeniu ośrodka i centrum kultury narodowej. Wówczas inteligencja dostała zadanie tworzenia od podstaw państwa i jego 
kultury. Twórcy nowego państwa i ówczesna inteligencja uzyskali wówczas bardzo szerokie możliwości wyboru form funkcjonowania państwa, jego organów, samorządu wszelkiego rodzaju i wszystkich stopni. Taka sytuacja nie powtórzyła się już nigdy. Nie powtórzyła się po 1945 r., gdy inteligencja stała się zagrożeniem dla reżimu, który skądinąd nie mógł się bez niej obejść. W rezultacie rola inteligencji była w latach 1945-1989 niepełna i zredukowana. Ale nie powtórzyła się także w 1989 r., gdyż scenariusz dla Polski był już praktycznie napisany i inteligencja mogła tylko współdziałać w dostosowaniu jej do ówczesnego „wolnego świata" w wyznaczonym miejscu. Zajmuję się tu historia, a nie przyszłymi wydarzeniami, które moga kiedyś zaapelować do inteligencji o nowy wysiłek na miarę tego z czasów odbudowy niepodległości.

Ale jakie były losy inteligencji - elity kulturalnej - w nowym porządku w Polsce po 1989 r.? Na to pytanie nie potrafiłbym dać zadowalającej odpowiedzi. Uprzedzę tylko wątpliwości i zauważę, że doszukanie się $\mathrm{w}$ naszej rzeczywistości istnienia klasy czy warstwy średniej nie załatwia sprawy. Klasa średnia to pojęcie z innego typu analizy. Dla nas istotne jest, co pozostało $\mathrm{z}$ dawnego pojęcia inteligencji i jego różnych desygnatów. Zauważę przede wszystkim, że istnieją uzasadnione wątpliwości co do dalszego istnienia inteligencji jako warstwy społecznej, o czym już wspominałem. Dziś mało kto posługuje się terminem „inteligencja" w tym znaczeniu. Z inteligencją jako twórcą i w dużej mierze odbiorcą kultury narodowej jest inna sprawa. Istnienie takiego czynnika czy takiego środowiska w każdej rzeczywistości nie podlega dyskusji. Jednak i w tym znaczeniu rzadko lub bardzo rzadko używa się dziś terminu „inteligencja”. Kategorie twórców kultury i ich audytoria są dzisiaj jakby rozproszone, jednoczą się wokół spraw zawodowych, często dość wąskich, nie pociagają ich sprawy ogólnospołeczne, polityczne, a jeżeli pociagaja, to nie jako przedstawicieli jakiejś kategorii intelektualistów, lecz jako mieszkańców danego zakątka, przedstawicieli jakiegoś szczególnego środowiska czy wreszcie zwolenników takiej czy innej ideologii politycznej, społecznej, artystycznej itp. Wydaje się, że rozrośnięte środowisko kultury jest już środowiskiem innego rodzaju niż tradycyjna inteligencja, jeszcze niedawno podpisujacca się swymi tytułami i zasługami pod ogólnopolitycznymi petycjami. Jeśli byłoby tak jak to opisuję, to i w takim rozumieniu pojęcie inteligencji straciłoby dawną nośność. Wydaje się, że znaczna część społeczeństwa nie akceptuje już odrębnej warstwy inteligenckiej, aspirującej do wyższości i wyłączności kulturalnej, tym bardziej że formalne wykształcenie plasowałoby bardzo znaczną część ludności w tejże warstwie. Czym innym sa intelektualiści jako grupa zawodowych twórców kultury, ale i ten 
termin stracił część albo i większość autorytetu, i nie słychać o jakichś próbach jego instytucjonalizacji.

W dyskusjach nad tymi problemami zwrócono mi uwagę, której nie można zlekceważyć, że procesy odnoszace się do inteligencji jako warstwy społecznej czy też jako kategorii/środowiska będącego nosicielem kultury narodowej są w skali całego społeczeństwa i całego kraju bardzo zróżnicowane. To, co z perspektywy Warszawy i inteligencji warszawskiej, a także z perspektywy innych aglomeracji ${ }^{22}$ wydaje się procesem zakończonym, gdzie indziej jest jeszcze w pełnym biegu, a niekiedy nawet nie jest specjalnie dostrzegalne. Mam na myśli zatarcie granic między warstwa inteligencji a podstawowym trzonem młodego pokolenia, które odebrało już wykształcenie na nowym, wyższym poziomie, co uznaję za istotna przesłankę rezygnacji z traktowania inteligencji jako warstwy. Mogę sobie wyobrazić, że procesy społeczne są zróżnicowane także w przekroju geograficznym i że pod określonym względem pewna część społeczeństwa znajduje się na takim, a inna na całkiem odmiennym etapie. Te procesy, o których tu piszę, trudno byłoby zobrazować na mapie, gdyż granice między nimi przebiegają nie między regionami, ale raczej między takimi kategoriami jak metropolie, miasta średniej wielkości, miasteczka i obszary wiejskie.

Same tylko dzieje Polski Ludowej liczą 45 lat, a od ich końca upłynęło już ponad ćwierć wieku. Trudno byłoby zakończyć omówienie dziejów inteligencji $\mathrm{w}$ tym czasie, nie wspominając o przemianach pokoleniowych. O sprawach tych w ujęciu cząstkowym pisałem w innym miej$\mathrm{scu}^{23}$. Wyróżnić trzeba pokolenie przedwojenne, urodzone przed $1939 \mathrm{r}$. (część przed 1914 r.), które dominowało aż do lat 50.-60., pokolenie, które rozpoczęło karierę zawodową czy intelektualną w okresie stalinizmu lub nieco później, wreszcie pokolenie urodzone już po okresie stalinizmu (w latach 60.-70.), które jeszcze odgrywa istotną rolę. Ale dziś funkcjonuje już w całej pełni następne pokolenie, które zaczęło samodzielną działalność już po 1989 r. i Polski Ludowej nie pamięta z własnych doświadczeń. O ile pierwsze $\mathrm{z}$ wymienionych pokoleń musiało

${ }^{22}$ Sądzić należy, że nie wszystkie aglomeracje w tej sprawie można traktować jednakowo i nie do wszystkich odnoszą się też moje refleksje. Inaczej interesujace nas kwestie przedstawiają się tradycyjnie inteligenckich aglomeracjach Warszawy czy Krakowa, inaczej na Górnym Śląsku, a jeszcze inaczej np. w Łodzi.

${ }^{23}$ J. Żarnowski, Pokolenia historyków po 1945 r. a przeobrażenia polskiej historiografii, „, Klio Polska. Studia i Materiały do Dziejów Historiografii Polskiej” 7, 2015, s. 15-42; tenże, Pokolenia historyków polskich po 1945 r. i ewolucja historiografii, w: Rok 1914. Jaka Polska, jaki świat? W kregu zainteresowań badawczych profesora Romana Wapińskiego, red. I. Sakowicz-Tebinka, Gdańsk 2016, s. 11-33. 
przyzwyczaić się do nowych komunistycznych porządków i rozwinęło wspomnianą wyżej taktykę współpracy z systemem i równoległego osiągania własnych celów, a kolejne pokolenie tę taktykę w lepszych nieco warunkach kontynuowało, to trzecie z wymienionych pokoleń mogło swą taktykę zmodyfikować, a wreszcie znalazło się w orbicie przemian i buntów lat 80. Historykowi najtrudniej zdać sobie sprawę z oblicza współczesnego pokolenia, które wciąż jest jakby in statu nascendi i nie wie dokładnie, co przyniosa następne lata, a zarazem korzysta z takich możliwości informacyjnych, technicznych i migracyjnych, o jakich nie śniło się jego poprzednikom.

Zdaję sobie sprawę, że w miarę ciagły wywód zawarty na powyższych stronach nie znajduje kontynuacji w odniesieniu do lat następujących po 1989 r., a to jest dziś już okres prawie trzydziestoletni! Do wypowiadania się o tym wcale nie krótkim, ale współczesnym okresie przystępuję z wielką ostrożnościa. Jest to zrozumiałe, gdyż ten obszar powinien być zarezerwowany dla socjologów czy przedstawicieli innych nauk społecznych, zajmujących się współczesnością i niewykazujących tendencji charakterystycznych dla historyka, który ogranicza swe wypowiedzi do epok czy odcinków czasu już zakończonych i dających się zobrazować w całości. Spróbujmy wyliczyć szczególne okoliczności odnoszące się do tego okresu i do naszego przedmiotu - inteligencji. Pierwszym oczywistym czynnikiem jest likwidacja dotychczasowych barier w przyswajaniu sobie dorobku naukowego i społecznego narodów pozostajacych pod władzą systemów demokratycznych, w naszym wypadku chodzi szczególnie o kraje europejskie. Wstapienie do Unii Europejskiej nie tylko zlikwidowało pozostałości wszelkich ograniczeń, ale też ułatwiło i umożliwiło kontakty i migracje nie tylko przejściowe, ale i stałe różnych środowisk, spośród nich zwłaszcza młodych pracowników naukowych i artystów. Oczywiście w tych migracjach wielką rolę odgrywają też Stany Zjednoczone.

Omawiany okres umożliwił dotarcie do Polski i przejmowanie bez przeszkód i ograniczeń ideologii i mód artystycznych, naukowych i obyczajowych z zewnątrz, to jest z demokratycznych krajów europejskich i z USA. Jest to praktyczny sprawdzian globalizacji, która ma swój wymiar gospodarczy, ideologiczny, techniczny, polityczny i obyczajowy. Trudno zapomnieć też o społeczno-technicznych, gospodarczych i obyczajowych skutkach informatyzacji i cyfryzacji, która w Polsce na szerszą skalę rozpoczęła się w tym samym czasie. Pod wieloma względami rewolucja informatyczna zmieniła charakter życia społecznego i profesjonalnego, nie tylko inteligencji, ale jednak zwłaszcza tej kategorii, przy czym inteligencja jest jednym z rozsadników tworzącego się świata informatycznego. 
Do niedawna wydawało się, że w przemianach społeczno-obyczajowych ostatnich czasów w grę wchodzi ujednostajnienie życia i funkcjonowania społeczeństw według wzorów wytworzonych w przodujących ośrodkach, w najbardziej rozwiniętych ekonomicznie i informatycznie krajach. Dziś już widać, że te procesy nie są oceniane tak samo przez wszystkich i zacieranie odrębności, zwłaszcza społeczeństw narodowych, budzi opór tych, którzy obawiają się, że wylądują w strefie rządzonej przez obce elity. Sa to oczywiście kwestie, które dla inteligencji w rozumieniu elity społeczeństwa narodowego sa zagadnieniem niesłychanie istotnym. Ale te sprzeczności ujawniły się niezbyt dawno i daleko jeszcze do tego, aby historyk wypowiadał się o związanych z nimi procesach. Można tylko zauważyć, że zarysowały się już fronty w tej sprawie, także w łonie polskiej inteligencji.

Inteligencja nie pozostaje poza zasięiem migracji, ale nie wydaje się, aby procesy migracyjne miały jakoś „osłabić” polską inteligencję, jeśli rozumiemy ją jako elitę intelektualną kraju. Warto zauważyć, że dotychczasowe procesy społeczne w ich wymiarze międzynarodowym ułatwiaja przenikanie jej członków do międzynarodowych elit naukowych i artystycznych, i usuwaja podłoże dawnych frustracji. Czy jednak bilans osiagnięć polskiej inteligencji na forum międzynarodowym zaspokaja ambicje jej samej i szerszych środowisk?

\section{Uwagi końcowe}

Podsumowując te rozważania, skonfrontuję ze sobą uwagi dotyczące inteligencji jako warstwy społecznej oraz jako środowiska twórców kultury i ich bezpośredniego audytorium. W moim niedawno napisanym artykule poświęconym warstwie inteligencji sygnalizowałem, że wiele wskazuje na to, iż inteligencja jako warstwa społeczna czy społeczno-zawodowa w naszych czasach już nie funkcjonuje tak jak dawniej ${ }^{24}$. Sądzę, że najważniejsze przesłanki, by warstwa inteligencji nie mogła funkcjonować po dawnemu, powstawały stopniowo $\mathrm{w}$ dziesięcioleciach przed 1989 r., i były to przesunięcia natury strukturalnej. Po 1989 r. jeszcze się one pogłębiały. Inteligencja jako warstwa staje się (a może już się stała) pojęciem historycznym, przydatnym do analizy minionych epok (w ramach historii nowszej i najnowszej).

${ }^{24}$ J. Żarnowski, Inteligencja jako warstwa społeczna $w$ Polsce...; zob. jednak zastrzeżenia, poczynione wyżej, a odnoszące się do cząstkowego funkcjonowania dawnych pojęć o inteligencji, zwłaszcza poza metropoliami. 
Wspominałem już o konieczności znacznego zniuansowania sądów o istnieniu bądź zaniku warstwy inteligencji. Gdy w stolicy, być może, pożegnaliśmy już inteligencję $\mathrm{w}$ dawnym stylu, $\mathrm{w}$ niewielkim mieście rodziny cieszą się ze świeżo nabytego statusu inteligenckiego jednego ze swoich członków, dodajmy, że pierwszego (w tym znaczeniu) w rodzinie inteligenta (magistra czegoś tam). Uwagi tej nie sposób zlekceważyć. Otwiera ona problematykę równoległych w tym samym kraju, w tym samym społeczeństwie narodowym procesów kształtowania elit. Ale uwaga ta komplikuje niepomiernie obraz rzeczywistości społecznej.

Inteligencja rozumiana jako środowisko intelektualne, oparte przede wszystkim na kulturze narodowej i grupujące twórców wartości kultury i ich zaplecze oraz świadomą publiczność tej kultury - nie uległa zanikowi. Nie zawsze używany jest na określenie tych środowisk termin ,inteligencja”, co jest o tyle zrozumiałe, że budzi on często „warstwowe" skojarzenia. Jak się nam zdaje, pojęcia opisujące środowiska twórcze i ich szeroką otoczkę funkcjonują obecnie w rozmaity sposób $\mathrm{w}$ różnych środowiskach. Ma to związek z wielkim i rosnącym zróżnicowaniem samych środowisk intelektualnych i artystycznych, idacym w ślad za zróżnicowaniem nauk i sztuk, a także powstawaniem zupełnie nowych dyscyplin i subdyscyplin zarówno nauki, jak i sztuki. Trzeba też wskazać na pojawienie się nowych form uczestnictwa w kulturze, wypełniających przestrzeń między twórczością profesjonalna, odtwarzaniem i nieprofesjonalnym uczestnictwem w tworzeniu sztuki i jej niektórych form i gatunków. Można by doszukiwać się analogicznych, choć znacznie słabszych, zjawisk na polu nauki. Nie ma więc jednego środowiska wyższej kultury, lecz wiele odgałęzień, czasem niewiedzących nawet o sobie nawzajem, a jednak wchodzących w skład kultury narodowej, przy tym nieraz widocznych także w przestrzeni europejskiej i globalnej. Należą tu wszelkie środowiska zainteresowane kultura i jej rozwojem, rozpowszechnieniem, utrwaleniem i obrona, oczywiście legitymujące się odpowiednim poziomem intelektualnym umożliwiającym uczestnictwo w procesach kulturotwórczych. W tym stanie rzeczy trudno dziwić się różnorodności terminologii.

Jakakolwiek nazwa przylgnęłaby do tych grup, zawsze społeczeństwo potrzebować będzie i zawsze wytworzy tak czy inaczej nazwana elitę kulturalna, której część sama twórczo kształtować będzie kulturę narodowa, wnosząc też pewne wartości do kultury współczesnej Europy czy Zachodu. Ale nie będzie to kontynuacja inteligencji w znaczeniu dziewiętnasto- czy dwudziestowiecznym. Będzie to raczej ogół środowisk kulturotwórczych, rozsianych po różnych częściach społeczeństwa, wraz z otoczką odbiorców kultury, znacznie szerszą niż dawniej, 
ale też znacznie bardziej zróżnicowana. Środowiska te nie mają już i z pewnością nie będą miały w przyszłości cech warstwy społecznej, lecz tylko charakter elity intelektualnej czy kulturowej w znaczeniu twórczym i odtwórczym, położonej jakby w poprzek hierarchicznych struktur społecznych i w bardzo różnych grupach, częściach czy zakątkach społeczeństwa.

Jeśli nasze spostrzeżenia i domysły są trafne, to przyłożenie terminu „inteligencja” do tego stale zmieniającego się środowiska nie powinno budzić zasadniczych zastrzeżeń. Punktem ciężkości tych rozważań sa rzeczywiste role społeczne, nie zaś same terminy. Analiza tych ról społecznych wskazuje na zachodzace $\mathrm{w}$ ostatnich dziesięcioleciach przeobrażenia, które w krótkim i uproszczonym wywodzie starałem się tu przedstawić.

\section{Bibliografia}

Dąbrowska M., Dzienniki 1914-1965 w 13 tomach, Warszawa 2009.

Fijałkowska B., Polityka i twórcy (1948-1959), Warszawa 1985.

Fik M., Kultura polska po Jatcie. Kronika lat 1944-1981, Londyn 1989.

Hass L., Inteligencji polskiej dole i niedole: XIX i XX wiek, Łowicz 1999.

Inteligencja w Polsce: specjaliści, twórcy, klerkowie, klasa średnia?, red.

H. Domański, Warszawa 2008.

Iwaszkiewicz J., Dzienniki, t. 1-3: 1911-1980, Warszawa 2007-2011.

Rakowski M., Dzienniki polityczne [1958-1990], Warszawa 1998-2005.

Żarnowski J., Nowe spojrzenie na społeczeństwo Polski międzywojennej, w: Spoteczeństwo międzywojenne. Nowe spojrzenie, red. W. Mędrzecki, J. Żarnowski, Warszawa 2015 (Metamorfozy Społeczne, 10), s. 13-46.

Żarnowski J., Rola państwa w kształtowaniu społeczeństwa Polski międzywojennej. Zarys problemu i uwagi wstępne, w: Państwo i społeczeństwo Drugiej Rzeczypospolitej. Zbiór studiów, red. J. Żarnowski, Warszawa 2014 (Metamorfozy Społeczne, 8), s. 9-32.

Żarnowski J., Społeczeństwo Drugiej Rzeczypospolitej: 1918-1939, Warszawa 1973.

Żarnowski J., Struktura spoteczna inteligencji w Polsce w latach 1918-1939, Warszawa 1964.

Żółkiewski S., Kultura literacka 1918-1932, Warszawa 1973. 
Janusz Żarnowski

Polish intellectuals, their historical evolution before and after the Second World War

(Summary)

The intelligentsia (in a social sense) - is a wide-ranging and equivocal concept. In my early research into the intelligentsia I regarded this group as a socio-professional stratum. Today, this concept has lost a bit of its significance for the intelligentsia understood as the intellectual elite of the nation, the bearer and distributor of national culture. This milieu is much narrower than the strata I focused on in my study of 1964. But broader than writers and painters or outstanding scholars only, for example professors of new Polish universities, broader than just "intellectuals" - the term was coming into use. People educated before WWII, but with the addition of a generation educated in Polish universities or Polish artistic institutions, formed a category of conscious and active recipients of values of social, intellectual, and artistic culture. This group often included educated people practising practical professions. These various categories and milieus formed a broad circle of participants of higher culture in Poland, mainly of the Polish national culture. Usually, all those social environments were included in the professional intelligentsia. The interwar period marked an apogee of this role of the Polish intelligentsia under discussion. In a certain sense, it was the intelligentsia who wrote constitutions, laws and statutes, curricula and schoolbooks, military regulations and fiscal ordinances.

The intelligentsia tended to be divided into two political orientations: leftist-legionary-liberal and national-rightist. The May Coup gave advantage to the first one, with the liberal intelligentsia and - to a certain extent - also the leftist intellectuals retaining their authority from before the war, when the "independence camp" was being constructed, associated with Piłsudski, the Polish Socialist Party, and various leftist-liberal milieus. The conservative-national orientation included opponents of the ruling camp. There were also other directions, including communist sympathies, most often among the assimilated intelligentsia of Jewish origin. It was the intelligentsia that brought about achievements of interwar Poland, such as the foundations of modern family relations, the new position of women, etc. But also the national camp and the Catholic Church contributed to Polish interwar achievements. All this, however, was destroyed by the Second World War, and especially by the German aggression and the annexation of eastern Polish territories by the USSR. After 1945, the intelligentsia who survived the war and stayed in the country tried to reconstruct the old cultural structures, but were attacked by the communist regime. Soon, Stalin died, and the crisis of communism began, more strongly felt in Poland than elsewhere. The Party lost some of their authority, and it was the intelligentsia that remained the centre of national culture and model for many people put on a route to schools and social advancement. This 
is one of the most outstanding achievements of the intelligentsia after 1956. It had a great impact on the Polish culture and even on politics from the 1950s to the 1980s. Scientific and artistic circles internalised many achievements and accomplishments of science and culture of the West. All this was attained in certain cooperation, and at the same time rivalry between the intelligentsia and the Party, and regime. The Party did not succeed in attracting young generations of people, who stayed under the influence of intellectual milieus. An important role was also played by the Catholic Church. The collapse of the Soviet bloc and "socialist" economy led to the crisis of the 1980s in Poland, and finally to the fall of communism in Eastern Europe. In a new situation and new political system, with a significant development of sciences and education, the old stratum of intelligentsia seems to diminish in significance in favour of the intelligentsia in a narrow sense of the term, the centre of all artistic creativity and national culture.

Janusz Żarnowski - prof. dr hab., historyk, ur. 1932. Studia w Uniwersytecie Warszawskim, uk. 1954, doktorat 1960, habilitacja 1964, prof. zw. 1981. W latach 1956-2009 pracował w Instytucie Historii PAN, potem m.in. w Uczelni Łazarskiego. Kierunki badań: historii Polski 1918-1939, historia społeczeństwa polskiego w XIX i XX w., ze szczególnym uwzględnieniem inteligencji i klasy robotniczej. W latach 2003-2011 przewodniczący Komitetu Nauk Historycznych PAN. Autor m.in.: Polska Partia Socjalistyczna w latach 1935-1936, Warszawa 1960; Struktura społeczna inteligencji $w$ Polsce $w$ latach 1918-1939, Warszawa 1964; Społeczeństwo Drugiej Rzeczypospolitej: 1918-1939, Warszawa 1973; „Ojczyzna byt język i mowa...” Kultura polska a odbudowa niepodlegtości w 1918 r., Warszawa 1978; Polska 1918-1939: praca, technika, społeczeństwo, Warszawa 1992 (wyd. 2 uzup. 1999); Społeczeństwa XX wieku, Wrocław 1999; State, Society and Intelligentsia. Modern Poland and its Regional Context, Aldershot 2003; Historia społeczna: metodologia, ewolucja, perspektywy, Warszawa 2011 (Metamorfozy Społeczne, 3). Pod jego redakcją ukazały się m.in.: Dyktatury w Europie Środkowo-Wschodniej: 1918-1939, Wrocław 1973 (ang. Dictatorships in East Central Europe 1918-1939, Wrocław 1983); W. Mędrzecki, S. Rudnicki, J. Żarnowski, Spoteczeństwo polskie w XX wieku, Warszawa 2003, i kilkanaście innych prac zbiorowych.

Janusz Żarnowski - (b. 1932), full professor since 1981, in 1956-2009 employed at the Institute of History of the Polish Academy of Sciences, then at the Lazarski University, and others; his research interests include: the history of Poland 1918-1939, history of the Polish society in the $19^{\text {th }}$ and $20^{\text {th }}$ century, with special attention to the intelligentsia and working class; in 2003-2011 the Chair of the Committee of Historical Sciences of the Polish Academy of Sciences. Author of books (selected): Polska Partia Socjalistyczna w latach 
1935-1939 (Polish Socialist Party in 1935-1939), Warsaw, 1960; Struktura spoteczna inteligencji $w$ Polsce $w$ latach 1918-1939 (Social Structure of the Intelligentsia in Poland in 1918-1939), Warsaw, 1964; Społeczeństwo Drugiej Rzeczypospolitej: 1918-1939 (The Society of the Second Polish Republic: 1918-1939), Warsaw, 1973; „Ojczyzna byt jezzyk $i$ mowa...” Kultura polska a odbudowa niepodlegtości $w 1918$ r. ("The Fatherland was the Language and Mother Tongue...” Polish Culture and the Rebuilding of Independence in 1918), Warsaw, 1978; Polska 1918-1939: praca, technika, spoteczenstwo (Poland 1918-1939: Work, Technology, Society), Warsaw, 1992 (2 $2^{\text {nd }}$ ed. 1999); Społeczeństwa XX wieku (The Societies of the Twentieth Century), Wrocław, 1999; State, Society and Intelligentsia. Modern Poland and its Regional Context, Aldershot 2003; Historia spoteczna: metodologia, ewolucja, perspektywy (Social History: Methodology, Evolution, Prospects), Warsaw, 2011, in the series "Metamorfozy Społeczne", vol. 3. He was the editor of, among others: Dyktatury w Europie Środkowo-Wschodniej 1918-1939, Wrocław 1973 (published in English in 1983 as: Dictatorships in East-Central Europe); and, in cooperation with W. Mędrzecki, and S. Rudnicki, Spoteczenstwo polskie w XX wieku (The Polish Society of the Twentieth Century), Warsaw, 2003, and several others.

E-mail: j-zarnowski@wp.pl. 